\title{
Temporal variability of phytoplankton biomass and primary production off Magdalena Bay, Baja California Sur, Mexico
}

\section{Variabilidad temporal de la biomasa y la producción primaria del fitoplancton frente a bahía Magdalena, Baja California Sur, México}

\author{
Rafael Cervantes-Duarte ${ }^{1 *}$, Sofía Barón-Campis², David Uriel Hernández-Becerril³, \\ Gilberto Gaxiola-Castro ${ }^{4 \dagger}$, J Rubén Lara-Lara ${ }^{4}$ \\ ${ }^{1}$ Instituto Politécnico Nacional, Centro Interdisciplinario de Ciencias Marinas, Av. Instituto Politécnico \\ Nacional, s/n, Colonia Playa Palo de Santa Rita, CP 23096, La Paz, Baja California Sur, Mexico. \\ 2 Instituto Nacional de Pesca, Secretaría de Agricultura, Ganadería, Desarrollo Rural, Pesca y Alimentación. \\ Pitágoras 1320, Col. Sta. Cruz Atoyac, CP 03310, Mexico City. \\ 3 Instituto de Ciencias del Mar y Limnología, Universidad Nacional Autónoma de México, Circuito exterior, \\ s/n, Ciudad Universitaria, CP 04510, Coyoacán, Mexico City. \\ ${ }^{4}$ Centro de Investigación Científica y de Educación Superior de Ensenada, Carretera Ensenada-Tijuana, \\ no. 3918, Zona Playitas, CP 22860, Ensenada, Baja California, Mexico.
}

* Corresponding author. E-mail: rcervan@ipn.mx

\begin{abstract}
Sixteen monthly cruises were carried out at a station $6.5 \mathrm{~km}$ to the NW of the mouth of Magdalena Bay (Mexico) to study the temporal variability of phytoplankton biomass and primary production rates, and the response of phytoplankton to the prevailing hydrographic characteristics. During each cruise, temperature and salinity were measured in the water column, and discrete samples were collected to measure inorganic nutrient concentrations (nitrate, phosphate, and silicate) and chlorophyll $a$ content (as a proxy for phytoplankton biomass); in addition, in situ incubations were performed to estimate primary production (PP) rates using the ${ }^{14} \mathrm{C}$ technique. During spring and early summer (March-July), the water column at the study site was cold $\left(14.4^{\circ} \mathrm{C}\right.$ at $80 \mathrm{~m}$ depth and $17.7^{\circ} \mathrm{C}$ at the surface) and well mixed, with high nutrient concentrations (nitrate $=6.39 \mu \mathrm{M}$, phosphate $=0.91 \mu \mathrm{M}$, and silicate $=11.87 \mu \mathrm{M}$ ) at the surface, typical of intense upwelling systems. On the contrary, from August to February the water column was stratified $\left(23.5 \pm 3.2^{\circ} \mathrm{C}\right.$ above the thermocline and $17.0 \pm 1.7^{\circ} \mathrm{C}$ at $\left.80 \mathrm{~m} \mathrm{depth}\right)$ and had low nutrient concentrations (nitrate $=3.90 \mu \mathrm{M}$, phosphate $=0.47 \mu \mathrm{M}$, and silicate $=10.30 \mu \mathrm{M}$ ) at the surface. Phytoplankton abundance, chlorophyll $a$ concentration, and PP rates in the euphotic zone were higher during the upwelling season, with maximum cell density of $1.7 \times 10^{6}$ cells $\cdot \mathrm{L}^{-1}$ (nanoplankton fraction), integrated chlorophyll $a$ content of $231 \mathrm{mg} \cdot \mathrm{m}^{-2}$, and integrated PP rates of $553 \mathrm{mg} \mathrm{C} \cdot \mathrm{m}^{-2} \cdot \mathrm{h}^{-1}$ ). Abundance of cells $<20 \mu \mathrm{m}$, as determined by flow cytometry, revealed the importance of the nanoplankton and picoplankton fractions in this region. This study showed the seasonal variability of phytoplankton communities (biomass and productivity) in waters off Magdalena Bay and the coupling of phytoplankton to environmental variability. Seasonal variability was similar to that observed for other typical coastal upwelling regions, that is, higher phytoplankton abundances and PP rates in spring and summer and lower values in autumn and winter.
\end{abstract}

Key words: biomass, primary productivity, hydrography, coastal zone, Magdalena Bay.

RESUMEN. En el periodo de la primavera de 2013 al verano de 2014 se llevaron a cabo 16 muestreos mensuales a $6.5 \mathrm{~km}$ al noroeste de la boca de bahía Magdalena (México) con el propósito de estudiar la variabilidad temporal de la biomasa y las tasas de producción primaria del fitoplancton y la respuesta del mismo a las características hidrográficas predominantes. En cada muestreo se midieron la temperatura y salinidad en la columna de agua y se determinaron las concentraciones de nutrientes inorgánicos (nitrato, fosfato y silicato) y el contenido de clorofila $a$ (como proxy de la biomasa del fitoplancton); además, se hicieron incubaciones in situ para estimar la producción primaria (PP) con el método de ${ }^{14} \mathrm{C}$. En primavera y principios de verano (marzo-julio), el sitio presentó, en promedio, una columna de agua fría $\left(14.4{ }^{\circ} \mathrm{C}\right.$ a $80 \mathrm{~m}$ de profundidad y $17.7^{\circ} \mathrm{C}$ en superficie) y mezclada con concentraciones de nutrientes altas en superficie (nitrato $=6.39 \mu \mathrm{M}$, fosfato $=0.91 \mu \mathrm{M}$ y silicato $=11.87 \mu \mathrm{M}$; valores característicos de zonas de afloramiento intenso). Por el contrario, de agosto a febrero se observó una columna de agua estratificada $\left(23.5 \pm 3.2^{\circ} \mathrm{C}\right.$ arriba de la termoclina y $17.0 \pm 1.7^{\circ} \mathrm{C}$ a $80 \mathrm{~m}$ de profundidad $)$ con menor contenido de nutrientes en superficie (nitrato $=3.90 \mu \mathrm{M}$, fosfato $=0.47 \mu \mathrm{M}$ y silicato $=10.30 \mu \mathrm{M}$ ). La abundancia del fitoplancton, la concentración de clorofila $a$ y las tasas de PP en la zona eufótica fueron mayores en la temporada de surgencias, con densidad celular máxima de $1.7 \times 10^{6}$ cél· $\mathrm{L}^{-1}$ (fracción del nanoplancton), contenido de clorofila $a$ integrada de $231 \mathrm{mg} \cdot \mathrm{m}^{-2}$ y tasa de producción integrada de $553 \mathrm{mg} \mathrm{C} \cdot \mathrm{m}^{-2} \cdot \mathrm{h}^{-1}$. Las abundancias de células $<20 \mu \mathrm{m}$ determinadas por citometría de flujo mostraron la importancia de las fracciones del nano y picoplancton en la región. Este estudio mostró la variabilidad estacional de las comunidades del fitoplancton (biomasa y productividad) en las aguas frente a bahía Magdalena y su acoplamiento al cambio ambiental. La variabilidad estacional fue similar a la observada en otras regiones características de afloramientos costeros, esto es, mayores abundancias y tasas de PP en primavera y verano y valores menores en otoño e invierno.

Palabras clave: biomasa, productividad primaria, hidrografía, zona costera, bahía Magdalena. 


\section{INTRODUCTION}

In general, coastal upwelling areas are the most productive zones in the marine environment, especially the ones in regions with eastern boundary currents (Hill et al. 1998). High phytoplankton biomass (chlorophyll $a \sim 150 \mathrm{mg} \cdot \mathrm{m}^{-2}$ ) and primary production $\left(\sim 3.5 \mathrm{~g} \mathrm{C} \cdot \mathrm{m}^{-2} \cdot \mathrm{d}^{-1}\right)$ values are observed during upwelling events. Although these coastal ecosystems make up only $1 \%$ of the ocean surface, they provide $\sim 11 \%$ of the $7.2 \mathrm{Gt} \mathrm{C} \cdot \mathrm{y}^{-1}$ of new production (Chavez and Toggweiler 1995). For instance, in the Peruvian-Chilean coastal system, one of the most productive coastal systems in the world (4 to $20 \mathrm{~g} \mathrm{C} \cdot \mathrm{m}^{-2} \cdot \mathrm{d}^{-1}$, Daneri et al. 2000), upwelling of deep waters with high partial pressure of carbon dioxide, low temperatures, low oxygen concentrations, and high nutrient concentrations (e.g., Strub et al. 1998) results in high phytoplankton productivity within a narrow coastal band. This high productivity is mainly due to the contribution of large cells $(>20 \mu \mathrm{m})$ such as diatoms, which is prompted by an increase in nitrate concentrations (Chavez and Messié 2009, Varela et al. 2010). During upwelling relaxation periods, however, there is an increase of nanoplankton cells $(<5 \mu \mathrm{m})$ and heterotrophic bacteria (Wetz and Wheeler 2004, Sherr et al. 2005).

The California Current is a cold current; at its southern limit, it is influenced by warm subtropical climate and the confluence of coastal currents flowing from the equator northward (Durazo and Baumgartner 2002, Durazo 2009). Off the western coast of the Baja California Peninsula, Mexico, several coastal upwelling areas (Walsh et al. 1977, Zaytsev et al. 2003) with increasing phytoplankton $\left(\sim 50 \times 10^{6}\right.$ cells $\left.\cdot \mathrm{L}^{-1}\right)$ and zooplankton $\left(\sim 1 \mathrm{~g} \cdot \mathrm{m}^{-3}\right.$ wet weight) biomass during upwelling events (Cervantes-Duarte et al. 1993, MartínezLópez and Verdugo-Díaz 2000) have been identified and studied. Upwelling intensity along the peninsula decreases towards the tropics; the coastal area off Magdalena Bay is the southernmost upwelling area and the one with the least upwelling intensity (Zaytsev et al. 2003, Auad et al. 2011). However, the Magdalena-Almejas area is one of the most productive and biologically diverse lagoon systems on the Pacific coast of Mexico (Lluch-Belda et al. 2003), and it is therefore an area with a high percentage of fishery production in Baja California Sur, a state occupying fourth place in fishery production nationwide (CONAPESCA 2013). The seasonal variation of hydrographic conditions and its relation to primary production in the region have been studied by Kahru et al. (2009) and Cervantes-Duarte et al. (2015); these authors reported a latitudinal (south-north) productivity increase, with maximum values during intense upwelling periods. In addition, climate events such as El Niño affect phytoplankton communities along the coasts of Baja California, reducing diversity and increasing the contribution of subtropical groups such as coccolithophores (Hernández-Becerril et al. 2007). The objective of this study was therefore to evaluate the effect of environmental variability on phytoplankton biomass and

\section{INTRODUCCIÓN}

En general, las zonas costeras con eventos de surgencia son las más productivas del ambiente marino, especialmente aquellas ubicadas en regiones con corrientes de frontera oriental (Hill et al. 1998). Durante el desarrollo de los eventos de afloramiento se encuentran en estas zonas valores altos de biomasa del fitoplancton (clorofila $a \sim 150 \mathrm{mg} \cdot \mathrm{m}^{-2}$ ) y producción primaria $\left(\sim 3.5 \mathrm{~g} \mathrm{C} \cdot \mathrm{m}^{-2} \cdot \mathrm{d}^{-1}\right)$. Aunque constituyen solo cerca del $1 \%$ del área del océano, estos ecosistemas costeros proveen un estimado del $11 \%$ de los $7.2 \mathrm{Gt} \mathrm{C} \cdot \mathrm{año}^{-1}$ de la producción nueva (Chavez y Toggweiler 1995). Por ejemplo, en el sistema costero peruano-chileno, el cual es uno de los sistemas costeros más productivos del mundo $\left(4 \mathrm{a} 20 \mathrm{~g} \mathrm{C} \cdot \mathrm{m}^{-2} \cdot \mathrm{d}^{-1}\right.$, Daneri et al. 2000), las surgencias de aguas profundas con contenido alto de la presión parcial de dióxido de carbono, bajas temperaturas, bajas concentraciones de oxígeno y altas concentraciones de nutrientes (e.g., Strub et al. 1998) generan una productividad alta del fitoplancton en una banda costera angosta. Esta alta productividad se debe principalmente a la contribución de células grandes $(>20 \mu \mathrm{m})$ como diatomeas, promovida por el incremento de la concentración de nitrato (Chavez y Messié 2009, Varela et al. 2010). Por otro lado, en el periodo de relajación de los afloramientos ocurre un aumento en la abundancia de células del nanoplancton $(<5 \mu \mathrm{m})$ y bacterias heterótrofas (Wetz y Wheeler 2004, Sherr et al. 2005).

La corriente de California es una corriente fría; en su parte meridional presenta los efectos propios de un clima cálido subtropical y el encuentro con corrientes costeras de origen ecuatorial con dirección hacia el norte (Durazo y Baumgartner 2002, Durazo 2009). En la costa occidental de la península de Baja California, México, se han identificado y estudiado varias zonas de afloramiento costero (Walsh et al. 1977, Zaytsev et al. 2003) donde la biomasa del fitoplancton $\left(\sim 50 \times 10^{6} \mathrm{cé} l \cdot \mathrm{L}^{-1}\right)$ y zooplancton $\left(\sim 1 \mathrm{~g} \cdot \mathrm{m}^{-3}\right.$ peso húmedo) se incrementa durante los eventos de afloramiento (Cervantes-Duarte et al. 1993, Martínez-López y Verdugo-Díaz 2000). La intensidad de estos afloramientos a lo largo de la península disminuye en dirección hacia los trópicos, y siendo la zona frente a bahía Magdalena el punto más sureño, los afloramientos ahí son de menor intensidad (Zaytsev et al. 2003, Auad et al. 2011). Sin embargo, Magdalena-Almejas es uno de los sistemas lagunares con mayor productividad y diversidad biológica en la costa mexicana del Pacífico (Lluch-Belda et al. 2003), por lo cual allí se obtiene un elevado porcentaje de la producción pesquera de Baja California Sur, el estado que ocupa el cuarto lugar nacional en ese rubro (CONAPESCA 2013). La variación estacional de las condiciones hidrográficas y su relación con la producción primaria han sido investigadas en la región por Kahru et al. (2009) y Cervantes-Duarte et al. (2015); estos autores han reportado un incremento latitudinal, de sur a norte, de la productividad, con valores máximos en los periodos de surgencias intensas. Además, se ha observado que la comunidad del fitoplancton a lo largo de las costas de Baja California se ve afectada por eventos climáticos como 
Cervantes-Duarte et al.: Phytoplankton off Magdalena Bay

primary production off Magdalena Bay, Baja California Sur, Mexico.

\section{MATERIALS AND METHODS}

Hydrographic data and phytoplankton biomass and primary production data were collected monthly between April 2013 and August 2014 at a station off Magdalena Bay $\left(24.5^{\circ} \mathrm{N}, 112.1^{\circ} \mathrm{W}\right.$; Fig. 1) aboard the vessel CICIMAR-30. Temperature and salinity vertical profiles were obtained during each survey using a Sea-Bird Electronics 19 CTD. Water samples were collected at 5 depths corresponding to different irradiance levels $(100 \%, 33 \%, 10 \%, 3 \%$, and $1 \%)$; irradiance levels were estimated using Secchi disc water transparency measurements $\left(K_{d}=1.7 / Z_{D}\right.$, where $K_{d}$ is the diffuse attenuation coefficient $[\mathrm{m}]$ and $Z_{D}$ is the depth at which the Secchi disc can no longer be seen [m]; Kirk 1994). Water samples were collected with 5-L Niskin bottles to determine nitrate, phosphate, and silicate concentrations, chlorophyll $a$ contents, and phytoplankton biomass. In addition, water samples were collected with 2-mL Eppendorf tubes to count phytoplankton cells by flow cytometry. Samples were fixed with $100 \mu \mathrm{L}$ of $10 \%$ paraformaldehyde and frozen at $-10{ }^{\circ} \mathrm{C}$ until analysis (4 months after the last cruise). For the counts, 1:1 sample dilutions were prepared with filtered sea water and $10 \mu \mathrm{L}$ of microbeads measuring $10 \mu \mathrm{m}$ in diameter. Counts were performed using a Beckman Coulter CyAn ADP flow cytometer equipped with 3 excitation lasers (405, 488 , and $635 \mathrm{~nm}$ ) to measure size, complexity, and fluorescence (Watson 2005, Aquino-Cruz et al. 2013). Results were analyzed using Infinicyt 1.6.

Samples collected in 200-mL flasks between April and June 2013 were fixed with Lugol acetate and analyzed to determine cell abundance and the main phytoplankton species during intense upwelling periods (Zaytsev et al. 2003). Cells were then counted in 10,25 , and $50-\mathrm{mL}$ sedimentation chambers using the Utermöhl (1958) method and the criteria defined by Hasle (1978) and Andersen and Throndsen (2004). For the nutrient (except silicate) and chlorophyll $a$ analyses, $1 \mathrm{~L}$ of seawater was filtered through 25 -mm-diameter glass fiber filters ( $\mathrm{GF} / \mathrm{F}, \sim 0.7 \mu \mathrm{m}$ pore size). Nutrient concentrations and chlorophyll $a$ contents were analyzed by spectrophotometry (Strickland and Parsons 1972). Chlorophyll $a$ was extracted with $10 \mathrm{~mL}$ of $90 \%$ acetone, refrigerated for $24 \mathrm{~h}$, and analyzed with a Genesis 2 spectrophotometer (Venrick and Hayward 1984). To estimate primary production (PP) rates, duplicate samples were collected in $250-\mathrm{mL}$ polycarbonate bottles. Together with a dark bottle, the bottles containing the samples were inoculated with $5 \mu \mathrm{Ci}$ of $\mathrm{NH}^{14} \mathrm{CO}_{3}$ and incubated for $2 \mathrm{~h}$ at midday according to the Steeman-Nielsen (1952) method. Samples were then filtered through Nucleopore GN-6 filters $(0.45 \mu \mathrm{m}$ pore size). Filters were placed in $20-\mathrm{mL}$ scintillation vials with $0.5 \mathrm{~mL}$ of $10 \% \mathrm{HCl}$ for $3 \mathrm{~h}$ to purge carbon not fixed by photosynthesis; thereafter, $10 \mathrm{~mL}$ of scintillation fluid
El Niño, ya que reduce la diversidad y aumenta la contribución de grupos de origen subtropical como los cocolitofóridos (Hernández-Becerril et al. 2007). Por lo anterior, el objetivo de este estudio fue evaluar el efecto de la variabilidad ambiental sobre la biomasa y la producción primaria del fitoplancton frente a bahía Magdalena, Baja California Sur, México.

\section{MATERIALES Y MÉTODOS}

Los datos hidrográficos y de la biomasa y la producción primaria del fitoplancton se obtuvieron mensualmente de abril de 2013 a agosto de 2014 en una estación frente a bahía Magdalena $\left(24.5^{\circ} \mathrm{N}, 112.1^{\circ} \mathrm{W}\right.$; Fig. 1$)$, a bordo de la embarcación CICIMAR-30. En cada muestreo se realizaron perfiles verticales de temperatura y salinidad utilizando un CTD Sea-Bird Electronics 19. Se tomaron muestras de agua en 5 profundidades determinadas por el nivel de irradiancia $(100 \%, 33 \%$, $10 \%, 3 \%$ y $1 \%$ ); los porcentajes de irradiancia fueron calculados con base en la transparencia del agua, que fue medida con un disco de Secchi $\left(K_{d}=1.7 / Z_{D}\right.$, donde $K_{d}$ es el coeficiente de atenuación difusa $[\mathrm{m}]$ y $Z_{D}$ es la profundidad de desaparición del disco de Secchi [m]; Kirk 1994). Con una botella Niskin de $5 \mathrm{~L}$ de capacidad, se recolectaron muestras de agua para determinar las concentraciones de nitratos, fosfatos y silicatos, el contenido de clorofila $a$ y la biomasa del fitoplancton. Además, se recolectaron muestras de agua para el conteo del fitoplancton por citometría de flujo en tubos Eppendorf de $2 \mathrm{~mL}$. Las muestras se fijaron con $100 \mu \mathrm{L}$ de paraformaldehido al $10 \%$ y se mantuvieron en congelación a $-10{ }^{\circ} \mathrm{C}$ hasta su análisis (4 meses después de la última recolecta). Para dicho

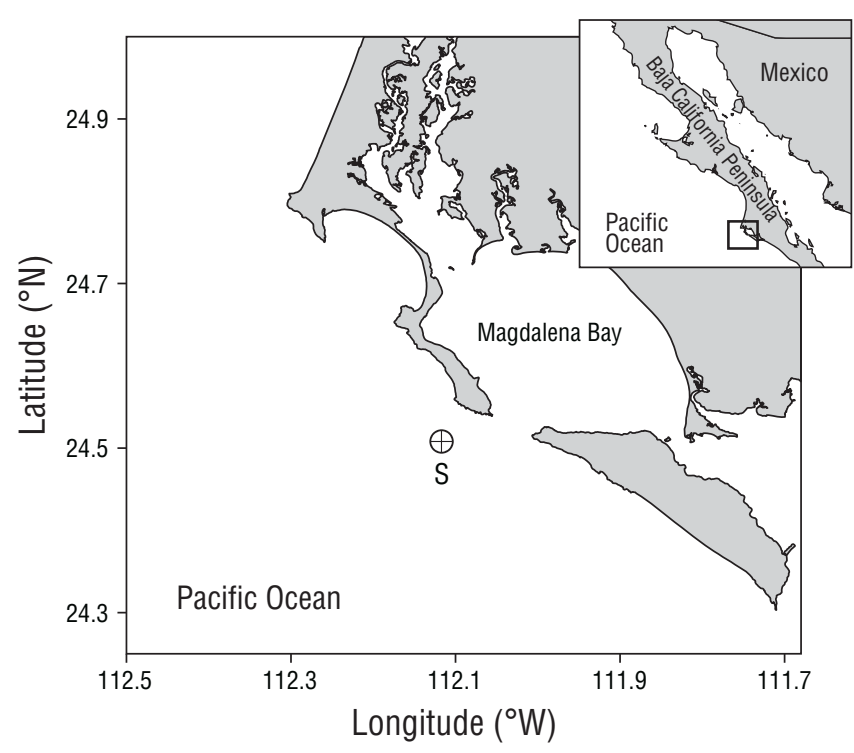

Figure 1. Study area showing the sampling site (S) $\left(24.5^{\circ} \mathrm{N}\right.$, $\left.112.1^{\circ} \mathrm{W}\right)$.

Figura 1. Área de estudio donde se indica el sitio de muestreo (S) $\left(24.5^{\circ} \mathrm{N}, 112.1^{\circ} \mathrm{W}\right)$. 
(Ecolite) were added and the activity was determined with a Beckman LS 6500 scintillation counter. Carbon assimilation by phytoplankton or PP $\left(\mathrm{mg} \mathrm{C} \cdot \mathrm{m}^{-3} \cdot \mathrm{h}^{-1}\right)$ was calculated with the equations used by Parsons et al. (1984). To analyze nutrient availability and nutrient uptake by phytoplankton, the nitrate:phosphate $(\mathrm{N}: \mathrm{P})$ and silicate:phosphate $(\mathrm{Si}: \mathrm{P})$ ratios were assessed for linearity and significance $(P<0.05)$ after performing a Pearson correlation with STATISTICA 8 software. The integration method used for the measured variables was the sum of the areas of simple polygons.

\section{RESULTS}

\section{Hydrographic characteristics}

Temperature, salinity, and density showed seasonal patterns. Relatively cold periods were observed from May to June 2013 and from March to June 2014, and a warm period was observed from July 2013 to February 2014. The water column $(80 \mathrm{~m})$ was mixed during the cold period and stratified during the warm period (Fig. 2). During the cold months, temperature ranged from 13.09 to $25.02{ }^{\circ} \mathrm{C}$, salinity from 33.61 to 34.50 , and density from 22.90 to $25.95 \mathrm{~kg} \cdot \mathrm{m}^{-3}$. During the warm months (August-February), temperature ranged from
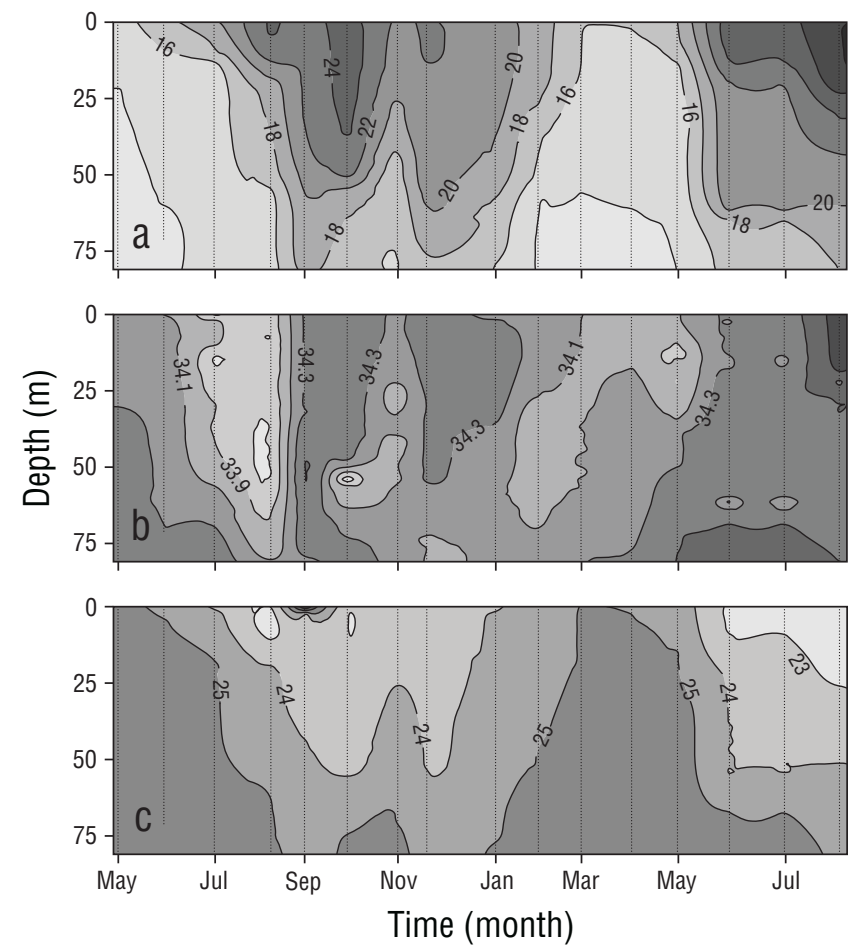

Figure 2. Temporal distribution for temperature $\left(\mathbf{a},{ }^{\circ} \mathrm{C}\right)$, salinity (b), and density $\left(\mathbf{c}, \mathrm{kg} \cdot \mathrm{m}^{-3}\right)$ at the sampling site. Data resolution $(1 \mathrm{~m})$ is indicated by dot frequency.

Figura 2. Distribución temporal de temperatura $\left(\mathbf{a},{ }^{\circ} \mathrm{C}\right)$, salinidad (b) y densidad $\left(\mathbf{c}, \mathrm{kg} \cdot \mathrm{m}^{-3}\right)$ en el sitio de muestreo. Los puntos indican la resolución de los datos $(1 \mathrm{~m})$. conteo, se preparó una dilución de la muestra 1:1 con agua de mar filtrada, y se agregaron $10 \mu \mathrm{L}$ de microesferas de $10 \mu \mathrm{m}$ de diámetro. Los conteos se realizaron en un citómetro CyAn ADP Beckman Coulter equipado con 3 láseres de excitación $(405,488$ y $635 \mathrm{~nm})$ para medir tamaño, complejidad y fluorescencia (Watson 2005, Aquino-Cruz et al. 2013). Los resultados se analizaron con el programa Infinicyt 1.6.

Para determinar la abundancia de células y las especies principales del fitoplancton en el periodo de surgencias intensas (Zaytsev et al. 2003), se analizaron las muestras disponibles (abril a junio de 2013), las cuales se recolectaron en frascos de $200 \mathrm{~mL}$ y se fijaron con acetato de lugol. Posteriormente, estas muestras se cuantificaron con el método de Utermöhl (1958) en cámaras de sedimentación de 10, 25 y $50 \mathrm{~mL}$, según los criterios de Hasle (1978) y Andersen y Throndsen (2004). Para los análisis de nutrientes (excepto silicato) y clorofila $a$, se filtró $1 \mathrm{~L}$ de agua de mar utilizando filtros de fibra de vidrio $(\mathrm{GF} / \mathrm{F})$ de $25 \mathrm{~mm}$ de diámetro y de aproximadamente $0.7 \mu \mathrm{m}$ de tamaño de poro. Las concentraciones de nutrientes y el contenido de clorofila $a$ fueron analizados por espectrofotometría (Strickland y Parsons 1972). La clorofila $a$ se extrajo con $10 \mathrm{~mL}$ de acetona al $90 \%$, se refrigeró durante 24 h y se analizó con un espectrofotómetro Génesis 2 (Venrick y Hayward 1984). Para calcular las tasas de la producción primaria (PP), se tomaron muestras por duplicado en botellas de policarbonato de $250 \mathrm{~mL}$. Junto con una botella oscura, las botellas con muestras se inocularon con $5 \mu \mathrm{Cide} \mathrm{NH}^{14} \mathrm{CO}_{3}$ y se incubaron durante $2 \mathrm{~h}$ al medio día, de acuerdo con el método descrito por Steeman-Nielsen (1952). Las muestras posteriormente se filtraron con filtros Nucleopore GN6 de $0.45 \mu \mathrm{M}$ de tamaño de poro. Los filtros se colocaron en viales de centelleo de $20 \mathrm{~mL}$ con $0.5 \mathrm{~mL}$ de $\mathrm{HCl}$ al $10 \%$ durante $3 \mathrm{~h}$ para excluir el carbono no fijado por fotosíntesis; luego, se agregaron $10 \mathrm{~mL}$ de solución de centelleo (Ecolite), y la actividad se cuantificó con un contador de centelleo líquido Beckman LS-6500. El carbono asimilado por el fitoplancton o PP $\left(\mathrm{mg} \mathrm{C}^{-3} \mathrm{~m}^{-3} \cdot \mathrm{h}^{-1}\right)$ se calculó de acuerdo con las ecuaciones de Parsons et al. (1984). Para investigar la disponibilidad y utilización de nutrientes por el fitoplancton, se analizó si las razones nitrato:fosfato $(\mathrm{N}: \mathrm{P})$ y silicato:fosfato (Si:P) eran lineales y significativas $(P<0.05)$ por medio de un análisis de correlación de Pearson con el programa STATISTICA 8. El método de integración utilizado para las variables medidas fue la sumatoria de áreas de polígonos simples.

\section{Resultados}

\section{Características hidrográficas}

La temperatura, salinidad y densidad presentaron patrones estacionales. Se observaron periodos relativamente fríos de mayo a junio de 2013 y de marzo a junio de 2014, y un periodo cálido de julio de 2013 a febrero de 2014. La columna de agua $(80 \mathrm{~m})$ estuvo mezclada en el periodo frío y estratificada en el periodo cálido (Fig. 2). En los meses fríos, la temperatura 
13.86 to $29.28{ }^{\circ} \mathrm{C}$ and the thermocline was deep $(\sim 50 \mathrm{~m})$ from August to October; salinity ranged from 33.68 to 34.70 and density from 21.74 to $25.54 \mathrm{~kg} \cdot \mathrm{m}^{-3}$ (Fig. 2).

\section{Nutrient distribution}

Variations in nitrate, phosphate, and silicate concentrations were observed with depth and the changing seasons of the year. In general, concentrations increased from the surface toward the bottom of the water column, which was mixed during the cold months and stratified during the warm months (Fig. 3). The integrated values of all nutrient concentrations in the water column showed that concentrations were higher during the cold period than during the warm period (Table 1).

The N:P ratio $(6.7: 1.0[r=0.76, n=48])$ for the MarchJuly period was significant $(P<0.05)$. The correlation for the August-February period $(10.3: 1.0[r=0.67, n=54])$ was also significant $(P<0.05)$. The Si:P ratio was 13.5:1.0 $(r=0.66$, $n=48)$ in the March-July period and 15.7:1.0 $(r=0.51, n=54)$ in the August-February period $(P<0.05)$.

\section{Phytoplankton biomass and primary production}

In general, phytoplankton biomass, for which chlorophyll $a$ concentration was used as proxy, and PP were highest at the surface. The chlorophyll $a$ and PP values for June at $100 \%\left(7.6 \mathrm{mg} \cdot \mathrm{m}^{-3}\right.$ and $80.4 \mathrm{mg} \mathrm{C} \cdot \mathrm{m}^{-3} \cdot \mathrm{h}^{-1}$, respectively) and $30 \%\left(7.9 \mathrm{mg} \cdot \mathrm{m}^{-3}\right.$ and $\left.78.1 \mathrm{mg} \mathrm{C} \cdot \mathrm{m}^{-3} \cdot \mathrm{h}^{-1}\right)$ light levels decreased toward the deeper part of the euphotic zone at $1 \%$ light level $\left(4.7 \mathrm{mg} \cdot \mathrm{m}^{-3}\right.$ and $\left.4.4 \mathrm{mg} \mathrm{C} \cdot \mathrm{m}^{-3} \cdot \mathrm{h}^{-1}\right)$ (Fig. 4). Average chlorophyll $a\left(2.6 \mathrm{mg} \cdot \mathrm{m}^{-3}\right.$ and $89 \mathrm{mg} \cdot \mathrm{m}^{-2}$, surface and integrated values, respectively) and integrated PP $\left(196 \mathrm{mg} \mathrm{C} \cdot \mathrm{m}^{-2} \cdot \mathrm{h}^{-1}\right)$ values for the March-July period were higher than the average chlorophyll $a\left(0.6 \mathrm{mg} \cdot \mathrm{m}^{-3}\right.$ and $\left.37 \mathrm{mg} \cdot \mathrm{m}^{-2}\right)$ and PP $\left(43 \mathrm{mg} \mathrm{C} \cdot \mathrm{m}^{-2} \cdot \mathrm{h}^{-1}\right)$ values for the AugustFebruary period (Table 2). The frequency of relatively high values, for both variables, was maximum during the cold period with respect to the warm period. During the study period the relation between chlorophyll $a$ and integrated chlorophyll $a$ in the euphotic zone showed a significant correlation $(r=0.90, n=17 ; P<0.05)$. Likewise, the correlation between integrated chlorophyll $a$ and integrated PP in the euphotic zone was significant $(r=0.70, n=17 ; P<0.05)$.

Abundance of phytoplankton cells $<20 \mu \mathrm{m}$, measured by flow cytometry, during the study period was highest in March-July, ranging from $0.1 \times 10^{6}$ cells $\cdot \mathrm{L}^{-1}$ (in July at $3 \%$ light level) to $66 \times 10^{6}$ cells $\cdot \mathrm{L}^{-1}$ (in June at the surface) (Fig. 5). In August-February values tended to be lower, ranging from $0.1 \times 10^{6}$ cells $\cdot \mathrm{L}^{-1}$ (in September at $10 \%$ light level) to $8 \times 10^{6}$ cells $\cdot \mathrm{L}^{-1}$ in September (at the surface).

Cell abundance, measured by microscopy, for April, May, and June 2013 showed that, in general, nanoplankton was more abundant than microplankton, with values ranging from $3.5 \times 10^{3}$ cells $\cdot \mathrm{L}^{-1}$ (in April at the surface) to $1.7 \times 10^{6}$ cells $\cdot \mathrm{L}^{-1}$ varió de 13.09 a $25.02{ }^{\circ} \mathrm{C}$, la salinidad de 33.61 a 34.50 y la densidad de 22.90 a $25.95 \mathrm{~kg} \cdot \mathrm{m}^{-3}$. En los meses cálidos (de agosto a febrero), la temperatura presentó un rango de 13.86 a $29.28^{\circ} \mathrm{C}$, y la termoclina fue profunda $(\sim 50 \mathrm{~m})$ de agosto a octubre; la salinidad presentó un rango de 33.68 a 34.70 y la densidad de 21.74 a $25.54 \mathrm{~kg} \cdot \mathrm{m}^{-3}$ (Fig. 2).

\section{Distribución de nutrientes}

Las concentraciones de nitratos, fosfatos y silicatos variaron tanto con la profundidad como con la época del año. En general, las concentraciones incrementaron de la superficie hacia el fondo de la columna de agua, la cual estuvo mezclada en los meses fríos y estratificada en los meses cálidos (Fig. 3). Los valores integrados de todas las concentraciones de nutrientes en la columna de agua mostraron que en el periodo frío las concentraciones fueron mayores respecto a los meses cálidos (Tabla 1).

La razón N:P $(6.7: 1.0[r=0.76, n=48])$ en el periodo de marzo a julio fue significativa $(P<0.05)$. Asimismo, en
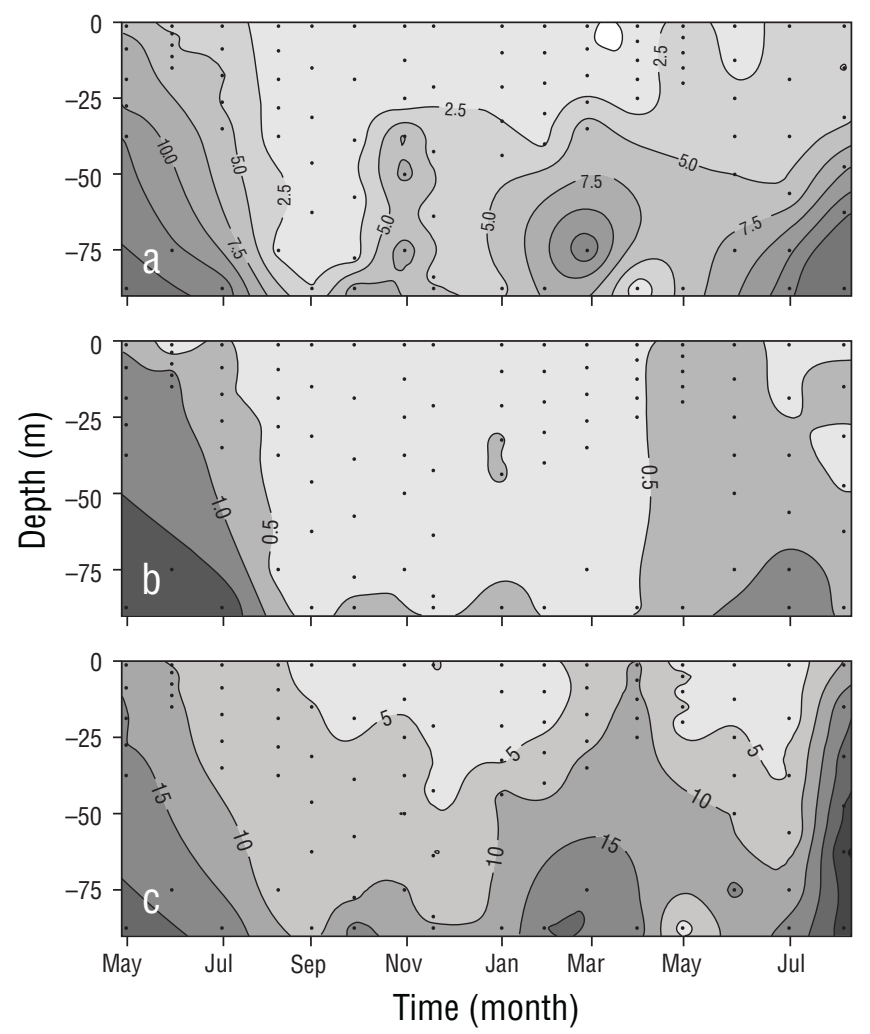

Figure 3. Temporal distribution for nitrate (a), phosphate (b), and silicate (c) concentrations $(\mu \mathrm{M})$ at the sampling site. Dots show sampling frequency ( 5 samples in the euphotic zone and 1 close to the bottom).

Figura 3. Distribución temporal de la concentración $(\mu \mathrm{M})$ de nitrato (a), fosfato (b) y silicato (c) en el sitio de muestreo. Los puntos indican la frecuencia de muestreo ( 5 muestras en la zona eufótica y 1 cerca del fondo). 
(in June at the surface) (Table 3). Microplankton during the same period ranged in abundance from 200 cells $\cdot \mathrm{L}^{-1}$ (in April at the surface) to $42.2 \times 10^{3}$ cells $\cdot \mathrm{L}^{-1}$ (in June at $3 \%$ light level) and was mainly dominated by diatoms and dinoflagellates. In general, diatoms were the most abundant species of microplankton, ranging from 120 cells $\cdot \mathrm{L}^{-1}$ (in April at the surface) to $26.5 \times 10^{3}$ cells $\cdot \mathrm{L}^{-1}$ (in June at $3 \%$ light level). Dinoflagellates showed maximum contributions $(>80 \%)$ to phytoplankton at 2 depths in June, with $15.7 \times 10^{3}$ and $11.2 \times 10^{3}$ cells $\cdot \mathrm{L}^{-1}$ at $3 \%$ and $1 \%$ light levels, respectively (Table 3 ).

\section{Discussion}

The monthly distribution of temperature, salinity, and density in the water column $(80 \mathrm{~m})$ for the period between May 2013 and August 2014 revealed at least 2 different oceanographic events. The first event was observed from March to June and it consisted in the presence of relatively cold and dense water that was distributed nearly homogeneously throughout the water column and was influenced mainly by water from the California Current (transitional water of subarctic origin). The second event was observed from August to el periodo de agosto a febrero la correlación (10.3:1.0 $[r=$ $0.67, n=54])$ fue significativa $(P<0.05)$. La razón Si:P fue 13.5:1.0 $(r=0.66, n=48)$ en el periodo de marzo a julio y 15.7:1.0 $(r=0.51, n=54)$ en el periodo de agosto a febrero $(P<0.05)$.

\section{Biomasa y producción primaria del fitoplancton}

La biomasa de fitoplancton, para la cual se usó como proxy la concentración de clorofila $a$, y la PP presentaron generalmente los valores más altos en la capa superficial. Los valores de clorofila $a$ y $\mathrm{PP}$ obtenidos para junio en los niveles de luz del $100 \%\left(7.6 \mathrm{mg} \cdot \mathrm{m}^{-3}\right.$ y $80.4 \mathrm{mg} \mathrm{C} \cdot \mathrm{m}^{-3} \cdot \mathrm{h}^{-1}$, respectivamente) y $33 \%\left(7.9 \mathrm{mg} \cdot \mathrm{m}^{-3}\right.$ y $\left.78.1 \mathrm{mg} \mathrm{C} \cdot \mathrm{m}^{-3} \cdot \mathrm{h}^{-1}\right)$ disminuyeron hacia el fondo de la zona eufótica en el nivel de luz del $1 \%\left(4.7 \mathrm{mg} \cdot \mathrm{m}^{-3}\right.$ y $\left.4.4 \mathrm{mg} \mathrm{C} \cdot \mathrm{m}^{-3} \cdot \mathrm{h}^{-1}\right)$ (Fig. 4). En el periodo de marzo a julio, los valores de clorofila $a\left(2.6 \mathrm{mg} \cdot \mathrm{m}^{-3} \mathrm{y}\right.$ $89 \mathrm{mg} \cdot \mathrm{m}^{-2}$, superficial e integrada, respectivamente) y PP integrada (196 $\mathrm{mg} \mathrm{C} \cdot \mathrm{m}^{-2} \cdot \mathrm{h}^{-1}$ ), en promedio, fueron más altos respecto a los valores de clorofila $a\left(0.6 \mathrm{mg} \cdot \mathrm{m}^{-3}\right.$ y $\left.37 \mathrm{mg} \cdot \mathrm{m}^{-2}\right)$ y PP integrada (43 $\mathrm{mg} \mathrm{C} \cdot \mathrm{m}^{-2} \cdot \mathrm{h}^{-1}$ ) para el periodo de agosto a febrero (Tabla 2). La frecuencia de valores relativamente altos de ambas variables fue máxima en el periodo frío respecto al

Table 1. Integrated values of nutrient concentrations $\left(\mathrm{mmol} \cdot \mathrm{m}^{-2}\right)$ in the water column $(0-80 \mathrm{~m})$ at the sampling site. **Extreme values not considered in the mean.

Tabla 1. Valores integrados de las concentraciones de nutrientes $\left(\mathrm{mmol} \cdot \mathrm{m}^{-2}\right)$ en la columna de agua $(0-80 \mathrm{~m})$ en el sitio de muestreo. **Valores extremos no considerados en el promedio.

\begin{tabular}{|c|c|c|c|c|c|c|}
\hline \multirow[b]{2}{*}{ Date } & \multicolumn{3}{|c|}{ March-July (cold) } & \multicolumn{3}{|c|}{ August-February (warm) } \\
\hline & Nitrate & Phosphate & Silicate & Nitrate & Phosphate & Silicate \\
\hline 27 Apr 2013 & 692 & $125^{* *}$ & $1,458 * *$ & & & \\
\hline 29 May 2013 & $869 * *$ & 97 & 1,237 & & & \\
\hline 28 Jun 2013 & 519 & 76 & 843 & & & \\
\hline $31 \mathrm{Jul} 2013$ & 563 & 78 & 761 & & & \\
\hline 06 Sep 2013 & & & & $81 * *$ & 17 & 421 \\
\hline 28 Sep 2013 & & & & 144 & 12 & 430 \\
\hline 26 Oct 2013 & & & & 96 & 12 & 498 \\
\hline 28 Nov 2013 & & & & 313 & 17 & 479 \\
\hline 17 Dec 2013 & & & & 191 & 13 & $315^{* *}$ \\
\hline 31 Jan 2014 & & & & 234 & 39 & 566 \\
\hline 28 Feb 2014 & & & & 233 & 12 & 695 \\
\hline 28 Mar 2014 & 340 & $17^{* *}$ & 718 & & & \\
\hline 30 Apr 2014 & $45^{* *}$ & 31 & 960 & & & \\
\hline 30 May 2014 & 359 & 55 & $217 * *$ & & & \\
\hline $03 \mathrm{Jul} 2014$ & 250 & 40 & 505 & & & \\
\hline 08 Aug 2014 & & & & 441 & $53 * *$ & 400 \\
\hline 13 Sep 2014 & & & & $687 * *$ & 44 & $1,635^{* *}$ \\
\hline Mean & 454 & 63 & 837 & 202 & 21 & 515 \\
\hline
\end{tabular}



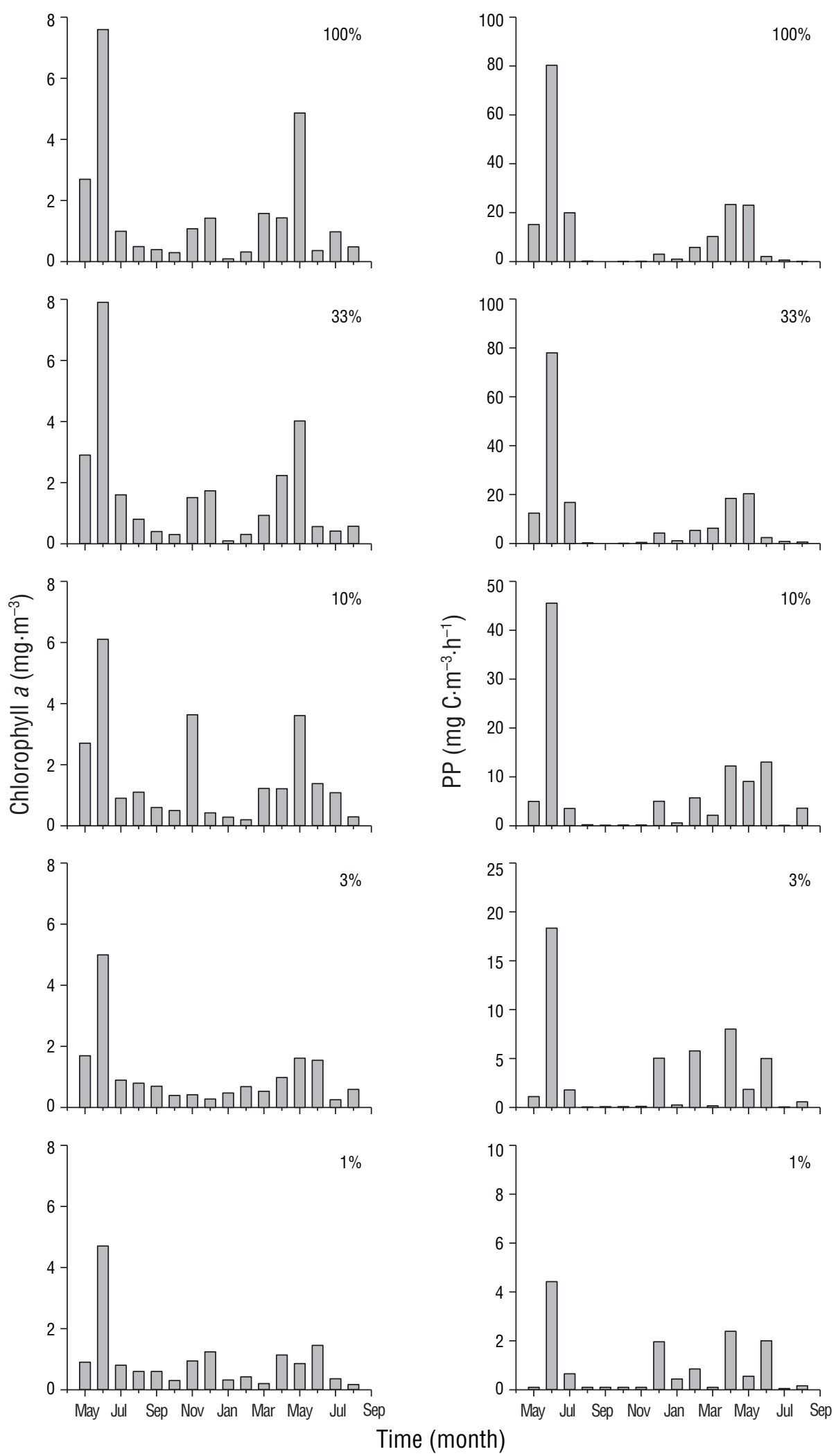

Figure 4. Variation of chlorophyll $a\left(\mathrm{mg} \cdot \mathrm{m}^{-3}\right)$ and primary production $(\mathrm{PP})$ rates $\left(\mathrm{mg} \mathrm{C} \cdot \mathrm{m}^{-3} \cdot \mathrm{h}^{-1}\right)$ at $100 \%, 33 \%, 10 \%, 3 \%$, and $1 \%$ light level at the sampling site.

Figura 4. Variación del contenido de clorofila $a\left(\mathrm{mg} \cdot \mathrm{m}^{-3}\right)$ y de las tasas de producción primaria $\left(\mathrm{PP}, \mathrm{mg} \mathrm{C} \cdot \mathrm{m}^{-3} \cdot \mathrm{h}^{-1}\right) \mathrm{en} \mathrm{el} 100 \%, 33 \%, 10 \%$, $3 \%$ y $1 \%$ de luz en el sitio de muestreo. 
February and it consisted in the presence of warm, less-dense water in the upper layers that was associated with water of tropical origin (Lynn and Simpson 1987, Zaitsev et al. 2014) (Fig. 6). Variation in nitrate, phosphate, and silicate concentrations at the study site showed that values were higher near the surface during the relatively colder months, when conditions were associated with intense upwelling (spring and early summer), and lower during the rest of the year, when water temperatures increased and upwelling events were weaker and less frequent (Durazo and Baumgartner 2002, Durazo 2009, Murillo-Murillo et al. 2013). The N:P and Si:P ratios in the water column were lower than the Redfield ratio (16N:1P) for oceanic waters but similar to ratios reported for coastal environments, where anthropogenic nutrient inputs are generally significant (Pilson 2013). The N:P ratio was lower in the March-July period than in August-February (6.7:1.0 and 10.3:1.0, respectively), indicating higher use of nitrogen from subsurface waters during upwelling processes. As a nutrient silicate differs from the inorganic compounds of nitrogen and phosphorus because it is not a universal requirement of organic matter (Redfield et al. 1963). However, the cálido. En el periodo de estudio, la relación clorofila $a$ versus clorofila $a$ integrada en la zona eufótica presentó una correlación significativa $(r=0.90, n=17 ; P<0.05)$. Asimismo, la relación clorofila $a$ integrada versus producción primaria integrada en la zona eufótica fue significativa $(r=0.70$, $n=17 ; P<0.05)$.

La abundancia de células de fitoplancton $<20 \mu \mathrm{m}$ medidas por citometría de flujo en el periodo de estudio fue más alta de marzo a julio, con un intervalo de $0.1 \times 10^{6}$ cél $\cdot \mathrm{L}^{-1}$ (en julio a la profundidad del $3 \%$ de luz) a $66 \times 10^{6}$ cél $\cdot \mathrm{L}^{-1}$ (en junio en superficie) (Fig. 5). De agosto a febrero los valores tendieron a ser menores, con un intervalo de $0.1 \times 10^{6} \mathrm{cél} \cdot \mathrm{L}^{-1}$ (en septiembre en el $10 \%$ de luz) a $8 \times 10^{6} \mathrm{cél}^{1} \cdot \mathrm{L}^{-1}$ (en septiembre en superficie).

La abundancia de células estimada por microscopía para abril, mayo y junio de 2013 mostró que, generalmente, el nanoplancton fue más numeroso que el microplancton, con valores de $3.5 \times 10^{3}$ cél $\cdot \mathrm{L}^{-1}$ (en abril en superficie) a $1.7 \times 10^{6}$ cél $\cdot \mathrm{L}^{-1}$ (en junio en superficie) (Tabla 3 ). El microplancton, en el mismo periodo, varió en abundancia de 200 cél $\cdot \mathrm{L}^{-1}$ (en abril en superficie) a $42.2 \times 10^{3}$ cél $\cdot \mathrm{L}^{-1}(\mathrm{en}$

Table 2. Surface chlorophyll $a\left(\mathrm{Chl} a, \mathrm{mg} \cdot \mathrm{m}^{-3}\right)$, integrated chlorophyll $a\left(\mathrm{Chl} a_{\mathrm{int}}, \mathrm{mg} \cdot \mathrm{m}^{-2}\right)$, and primary production integrated in the euphotic zone $\left(\mathrm{PP}_{\text {int }}, \mathrm{mg} \mathrm{C} \cdot \mathrm{m}^{-2} \cdot \mathrm{h}^{-1}\right)$ at the sampling site. **Extreme values not considered in the mean. Tabla 2. Valores de clorofila $a$ superficial $\left(\mathrm{Chl} a, \mathrm{mg} \cdot \mathrm{m}^{-3}\right)$, clorofila $a$ integrada $\left(\mathrm{Chl}_{\mathrm{int}}, \mathrm{mg} \cdot \mathrm{m}^{-2}\right)$ y producción primaria integrada en la zona eufótica $\left(\mathrm{PP}_{\mathrm{int}}, \mathrm{mg} \mathrm{C} \cdot \mathrm{m}^{-2} \cdot \mathrm{h}^{-1}\right)$ en el sitio de muestreo. **Valores extremos no considerados en el promedio.

\begin{tabular}{|c|c|c|c|c|c|c|}
\hline & \multicolumn{3}{|c|}{ March-July (cold) } & \multicolumn{3}{|c|}{ August-February (warm) } \\
\hline & Chla & Chla $a_{\text {int }}$ & $\mathrm{PP}_{\text {int }}$ & Chla & Chla $a_{\text {int }}$ & $\mathrm{PP}_{\text {int }}$ \\
\hline 27 Apr 2013 & 3.8 & 158 & $79 * *$ & & & \\
\hline 29 May 2013 & 2.7 & 100 & 193 & & & \\
\hline 28 Jun 2013 & $7.6^{* *}$ & $231^{* *}$ & $553 * *$ & & & \\
\hline $31 \mathrm{Jul} 2013$ & 1.0 & 55 & 228 & & & \\
\hline 06 Sep 2013 & & & & 0.5 & 41 & 7 \\
\hline 28 Sep 2013 & & & & 0.4 & 38 & $5 * *$ \\
\hline 26 Oct 2013 & & & & 0.3 & 25 & 8 \\
\hline 28 Nov 2013 & & & & 1.1 & $75 * *$ & 10 \\
\hline 17 Dec 2013 & & & & $1.4 * *$ & 68 & $286^{* *}$ \\
\hline 31 Jan 2014 & & & & $0.1 * *$ & $16^{* *}$ & 24 \\
\hline 28 Feb 2014 & & & & 0.3 & 25 & 163 \\
\hline 28 Mar 2014 & 1.6 & $34 * *$ & 98 & & & \\
\hline 30 Apr 2014 & 1.4 & 74 & 259 & & & \\
\hline 30 May 2014 & 4.9 & 85 & 173 & & & \\
\hline 03 Jul 2014 & $0.4^{* *}$ & 63 & 227 & & & \\
\hline 08 Aug 2014 & & & & 1.0 & 39 & 22 \\
\hline 13 Sep 2014 & & & & 0.5 & 26 & 65 \\
\hline Mean & 2.6 & 89 & 196 & 0.6 & 37 & 43 \\
\hline
\end{tabular}


silicate cycle corresponds in many ways with the phosphorus cycle, as depletion and remineralization occur simultaneously. The ratios of change (15Si:1P) were similar to the N:P ratios (Redfield et al. 1963). In general, the proportion of silicate concentrations to phosphorus and nitrate concentrations in the ocean varies greatly depending on the proportion of diatoms to other phytoplankton groups that do not require silica. Dissolution of diatom silica is believed to follow a path different from the oxidation of organic matter (Redfield et al. 1963). In this study the Si:P ratio was lower in March-July than in August-February (10.3:1.0 and 15.7:1.0, respectively), and this is probably associated with diatom abundance during this season (Martínez-López and Verdugo-Díaz 2000).

During the study period, phytoplankton biomass and PP varied with prevailing oceanographic conditions. The highest biomass and PP values were recorded in March-July (cold period) and were concomitant with the highest nutrient concentrations in the water column (Tables 1,2). Average chlorophyll $a$ concentrations of $>1 \mathrm{mg} \cdot \mathrm{m}^{-3}$ and $\mathrm{PP}$ values of $\sim 128 \mathrm{mg} \mathrm{C} \cdot \mathrm{m}^{-2} \cdot \mathrm{h}^{-1}$ could be considered distinctive characteristics of a coastal euphotic zone during this period (Gaxiola-Castro et al. 2010). Spring and summer are characterized by an increase in coastal upwelling events along the Baja California Peninsula, especially in March, April, and May (Zaytsev et al. 2003, Pérez-Brunius et al. 2007), and these upwelling events are also associated with the increase in the seasonal flow of the California Current (Durazo et al. junio en el 3\% de luz) y estuvo dominado, principalmente, por diatomeas y dinoflagelados. Las diatomeas fueron generalmente las especies más abundantes del microplancton con un intervalo de 120 cél $\cdot \mathrm{L}^{-1}$ (en abril en superficie) a $26.5 \times 10^{3}$ cél $\cdot \mathrm{L}^{-1}$ (en junio en el $3 \%$ de luz). Los dinoflagelados presentaron su máxima contribución $(>80 \%)$ al fitoplancton en 2 profundidades en junio con abundancias de $15.7 \times 10^{3}$ y $11.2 \times 10^{3}$ cél $\cdot \mathrm{L}^{-1}$ en el $3 \%$ y $1 \%$ de luz, respectivamente (Tabla 3 ).

\section{Discusión}

La distribución mensual de temperatura, salinidad y densidad en la columna de agua $(80 \mathrm{~m})$ en el periodo de mayo de 2013 a agosto de 2014 mostró al menos 2 eventos oceanográficos distintos. El primero se observó de marzo a julio y consistió en la presencia de agua relativamente fría y densa distribuida de manera casi homogénea con la profundidad e influenciada principalmente por agua de la corriente de California (agua de origen subártico y de transición). El segundo se observó de agosto a febrero y consistió en la presencia de agua cálida y menos densa en las capas más cercanas a la superficie, asociada con agua de origen tropical (Lynn y Simpson 1987, Zaitsev et al. 2014) (Fig. 6). La variación de las concentraciones de nitratos, fosfatos y silicatos en el sitio de estudio mostró que los valores fueron más altos cerca de la superficie en los meses relativamente más fríos, cuando las condiciones se relacionaron con afloramientos

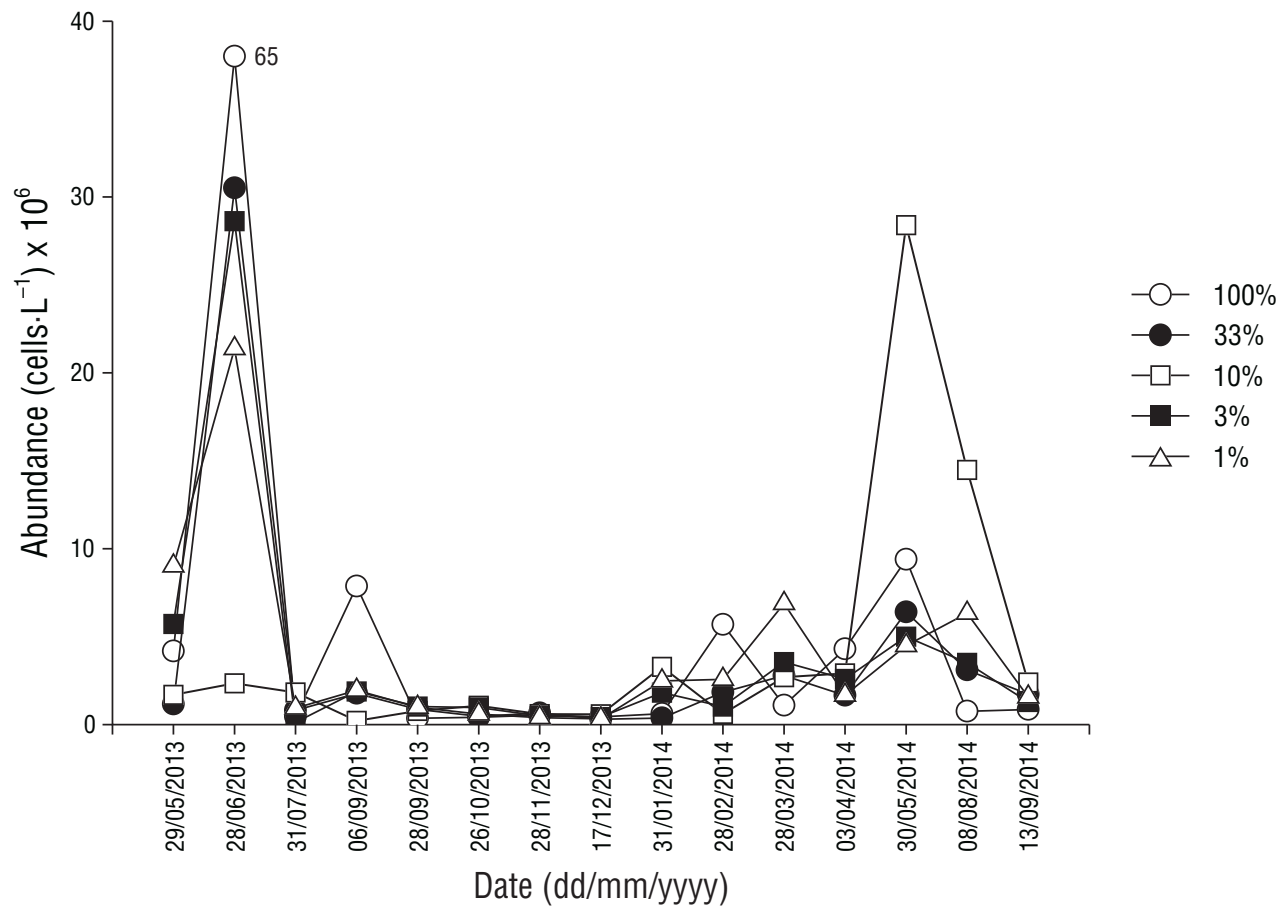

Figure 5. Distribution of phytoplankton abundance (cells $\left.\cdot \mathrm{L}^{-1}\right)$ at each light level at the sampling site.

Figura 5. Distribución de la abundancia de fitoplancton $\left(\right.$ cél $\left.\cdot \mathrm{L}^{-1}\right)$ por porcentaje de luz en el sitio de muestreo. 
2010). Both upwelling and the increased seasonal flow of this current boost nutrient inputs to surface waters, fertilizing the zone near the coast and stimulating greater phytoplankton growth (Gaxiola-Castro et al. 2010). According to information from the Pacific Fisheries Environmental Laboratory (https://www.pfeg.noaa.gov/products/PFEL/modeled/ indices/upwelling/NA/data_download.html), the highest biomass $\left(231 \mathrm{mg} \cdot \mathrm{m}^{-2}\right)$ and integrated PP $\left(553 \mathrm{mg} \mathrm{C} \cdot \mathrm{m}^{-2} \cdot \mathrm{h}^{-1}\right)$ values occurred in June 2013 at a site $\left(24^{\circ} \mathrm{N}\right.$ and $\left.113^{\circ} \mathrm{W}\right)$ under intense upwelling conditions (upwelling indices of 147 and $205 \mathrm{~m}^{3} \cdot \mathrm{s}^{-1}$ per $100 \mathrm{~m}$ of coastline for 29 and 30 June, respectively) and high nutrient concentrations (nitrate $=$ $519 \mathrm{mmol} \cdot \mathrm{m}^{-2}$, phosphate $=76 \mathrm{mmol} \cdot \mathrm{m}^{-2}$, and silicate $=$ $843 \mathrm{mmol} \cdot \mathrm{m}^{-2}$ ). These values are comparable to the maximum values observed in Cabo Corrientes $\left(447 \mathrm{mg} \mathrm{C} \cdot \mathrm{m}^{-2} \cdot \mathrm{h}^{-1}\right.$, López-Sandoval et al. 2009) and to values recorded in the Gulf of Ulloa, Baja California (Gaxiola-Castro et al. 2010). During the August-February period nutrient and chlorophyll $a$ concentrations and PP in the water column were lower with respect to the March-July period (Tables 1, 2). Average integrated chlorophyll $a$ was $37 \mathrm{mg} \cdot \mathrm{m}^{-2}$ and is comparable to the minimum $\left(25 \mathrm{mg} \cdot \mathrm{m}^{-2}\right)$ reported for the Mexican Investigations of the California Current (IMECOCAL) network in the autumn-winter period (Gaxiola-Castro et al. 2010). Valle-Rodríguez and Trasviña-Castro (2017) determined the presence of a poleward flowing current, with speeds of $0.2-0.3 \mathrm{~m} \cdot \mathrm{s}^{-1}$, near the coast of the Baja California Peninsula during the summer, and this current is probably responsible for the temperature maxima reported in this study. For the 1998-2007 period, the IMECOCAL program reported that in situ chlorophyll $a$ concentrations in winter and autumn were lower in comparison with the high spring values (Gaxiola-Castro et al. 2010). Phytoplankton biomass was higher during the intense upwelling period (March-July) intensos (primavera e inicios de verano), y fueron menores el resto del año, cuando la temperatura del agua se incrementó y los afloramientos eran débiles y de menor frecuencia (Durazo y Baumgartner 2002, Durazo 2009, Murillo-Murillo et al. 2013). Las razones N:P y Si:P en el agua fueron menores que la razón de Redfield (16N:1P) para aguas oceánicas, aunque similares a las reportadas para ambientes costeros, donde los aportes de nutrientes de origen antropogénico generalmente son significativos (Pilson 2013). En el periodo de marzo a julio la razón N:P fue menor que en el periodo de agosto a febrero (6.7:1.0 y 10.3:1.0, respectivamente), lo cual indica la mayor utilización de nitrógeno aportado por los procesos de afloramiento de agua subsuperficial. El silicato como nutriente difiere de los compuestos inorgánicos de nitrógeno y fósforo ya que no es un requerimiento universal de la materia orgánica (Redfield et al. 1963). Sin embargo, el ciclo del silicato se corresponde de muchas formas con el ciclo del fósforo, puesto que ambos se agotan y remineralizan simultáneamente. Las razones de cambio (15Si:1P) fueron similares a las razones N:P (Redfield et al. 1963). En general, la concentración de silicato en el océano varía mucho en su proporción con las concentraciones de fosfato y nitrato, debido a la proporción de las diatomeas con respecto a otros grupos de fitoplancton que no requieren sílice. Se supone que la disolución del sílice de las diatomeas sigue una ruta distinta a la oxidación de la materia orgánica (Redfield et al. 1963). En este estudio, la proporción Si:P fue menor en el periodo de marzo a julio respecto al periodo de agosto a febrero (10.3:1.0 y 15.7:1.0, respectivamente), lo cual probablemente está relacionado con la abundancia de diatomeas en ésta época (Martínez-López y Verdugo-Díaz 2000).

En el periodo de estudio, la biomasa y la PP del fitoplancton variaron de acuerdo con las condiciones oceanográficas prevalecientes. De marzo a julio (periodo frío) se registraron

Table 3. Phytoplankton abundance from April to June 2013.

Tabla 3. Abundancia de fitoplancton de abril a junio de 2013.

\begin{tabular}{|c|c|c|c|c|c|c|}
\hline Date & $\begin{array}{l}\text { Light } \\
(\%)\end{array}$ & $\begin{array}{l}\text { Depth } \\
\text { (m) }\end{array}$ & $\begin{array}{l}\text { Nanoplankton } \\
\left(\text { cells } \cdot \mathrm{L}^{-1}\right)\end{array}$ & $\begin{array}{l}\text { Microplankton } \\
\left(\text { cells } \cdot \mathrm{L}^{-1}\right)\end{array}$ & $\begin{array}{c}\text { Diatoms } \\
\left(\text { cells } \cdot \mathrm{L}^{-1}\right)\end{array}$ & $\begin{array}{l}\text { Dinoflagellates } \\
\quad\left(\text { cells } \cdot \mathrm{L}^{-1}\right)\end{array}$ \\
\hline 27 Apr 2013 & 100 & 0 & 3,528 & 200 & 120 & 80 \\
\hline 27 Apr 2013 & 3 & 15 & 11,893 & 2,243 & 2,019 & 224 \\
\hline 27 Apr 2013 & 1 & 20 & 38,597 & 1,795 & 1,496 & 299 \\
\hline 29 May 2013 & 100 & 0 & 9,425 & 5,386 & 3,142 & 2,244 \\
\hline 29 May 2013 & 33 & 7 & 99,183 & 28,723 & 25,133 & 3,590 \\
\hline 29 May 2013 & 10 & 15 & 109,356 & 1,116 & 1,116 & 0 \\
\hline 28 Jun 2013 & 100 & 0 & $1,714,520$ & 13,775 & 5,213 & 8,562 \\
\hline 28 Jun 2013 & 33 & 3 & 11,893 & 4,808 & 993 & 3,815 \\
\hline 28 Jun 2013 & 10 & 6 & 17,055 & 13,358 & 9,279 & 4,079 \\
\hline 28 Jun 2013 & 3 & 9 & 8,079 & 42,187 & 26,479 & 15,708 \\
\hline 28 Jun 2013 & 1 & 12 & 4,488 & 26,928 & 15,708 & 11,220 \\
\hline
\end{tabular}


compared to lower biomass values recorded during weak upwelling events (August-February) (Fig. 7).

The relation between surface chlorophyll $a$ and integrated chlorophyll $a$ and between integrated chlorophyll $a$ and integrated PP showed significant linear correlations during the study period. The equation (integrated chlorophyll $a)=[(24.6 \times$ surface chlorophyll a) +26 ] will allow estimating the integrated chlorophyll $a$ concentration in the euphotic zone using surface chlorophyll $a$ data. The correlation between integrated chlorophyll $a$ and integrated PP found in the present study was analogous to that reported for the IMECOCAL area for all 4 seasons of the year. The equation that allows estimating integrated PP from integrated chlorophyll $a$ data is the following: (integrated PP $)=[(1.8 \times$ integrated chlorophyll $a)+16]$.

Phytoplankton abundance, estimated by flow cytometry and by microscopy (April, May, and June), was dominated

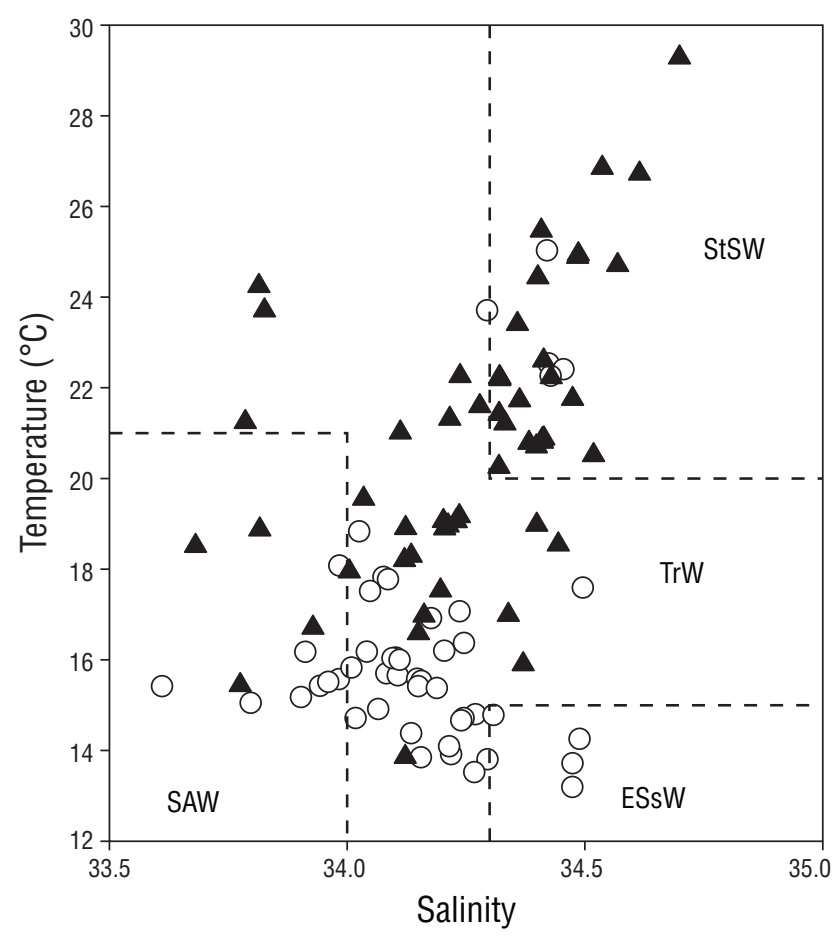

Figure 6. Temperature-salinity diagram drawn from data collected at the sampling depths $(0-80 \mathrm{~m})$. Empty circles correspond to data from the March-July period and filled triangles to data from the August-February period. Water masses were defined according to Durazo and Baumgartner (2002): SAW = Subartic Water; ESsW = Equatorial Subsurface Water; TrW = Transitional Water; and StSW = Subtropical Surface Water.

Figura 6. Diagrama de temperatura y salinidad construido a partir de los datos registrados en las profundidades donde se recolectaron muestras $(0-80 \mathrm{~m})$. Los círculos vacíos corresponden a datos del periodo de marzo a julio y los triángulos rellenos a datos del periodo de agosto a febrero. Las masas de agua se definieron de acuerdo con Durazo y Baumgartner (2002): SAW = Agua Subártica; ESsW = Agua Subsuperficial Ecuatorial; $\operatorname{TrW}=$ Agua Transicional; y StSW = Agua Superficial Subtropical. los valores más altos de biomasa y PP, que fueron concomitantes con las más altas concentraciones de nutrientes en la columna de agua (Tablas 1,2). En este periodo, una concentración promedio de clorofila $a$ mayor que $1 \mathrm{mg} \cdot \mathrm{m}^{-3} \mathrm{y}$ valores de PP de $\sim 128 \mathrm{mg} \mathrm{C} \cdot \mathrm{m}^{-2} \cdot \mathrm{h}^{-1}$ pueden considerarse como pertenecientes de una zona eutrófica costera (Gaxiola-Castro et al. 2010). Las épocas de primavera y verano se caracterizan por el incremento en los afloramientos costeros a lo largo de la península de Baja California, principalmente en marzo, abril y mayo (Zaytsev et al. 2003, Pérez-Brunius et al. 2007), y estos afloramientos, además, están asociados con el aumento del flujo estacional de la corriente de California (Durazo et al. 2010). Tanto las surgencias como el aumento del flujo de esta corriente incrementan el aporte de nutrientes hacia la superficie, lo que fertiliza la región cercana a la costa y genera un crecimiento mayor del fitoplancton (Gaxiola-Castro et al. 2010). De acuerdo con los valores obtenidos del Pacific Fisheries Environmental Laboratory (https://www.pfeg.noaa. gov/products/PFEL/modeled/indices/upwelling/NA/data download.html), en junio de 2013 se registraron en el sitio ubicado a $24^{\circ} \mathrm{N}$ y $113^{\circ} \mathrm{W}$ la mayor biomasa $\left(231 \mathrm{mg} \cdot \mathrm{m}^{-2}\right)$ y la mayor PP integrada $\left(553 \mathrm{mg} \mathrm{C} \cdot \mathrm{m}^{-2} \cdot \mathrm{h}^{-1}\right)$ bajo condiciones de surgencias intensas (índices de surgencia de 147 y $205 \mathrm{~m}^{3} \cdot \mathrm{s}^{-1}$ por $100 \mathrm{~m}$ de línea de costa para el 29 y 30 de junio, respectivamente) y altas concentraciones de nutrientes en la columna de agua $\left(519 \mathrm{mmol} \cdot \mathrm{m}^{-2}\right.$ de nitrato, $76 \mathrm{mmol} \cdot \mathrm{m}^{-2}$ de fosfato $\mathrm{y}$ $843 \mathrm{mmol} \cdot \mathrm{m}^{-2}$ de silicato). Estos valores son comparables con los máximos observados en cabo Corrientes $\left(447 \mathrm{mg} \mathrm{C} \cdot \mathrm{m}^{-2} \cdot \mathrm{h}^{-1}\right)$ (López-Sandoval et al. 2009) y con los valores registrados para el golfo de Ulloa, Baja California (Gaxiola-Castro et al. 2010). El periodo de agosto a febrero presentó menores concentraciones de nutrientes y clorofila $a$ y menor PP en la columna de agua respecto al periodo de marzo a julio (Tablas 1,2). La clorofila $a$ integrada promedio fue de $37 \mathrm{mg} \cdot \mathrm{m}^{-2} \mathrm{y}$ es comparable con la mínima $\left(25 \mathrm{mg} \cdot \mathrm{m}^{-2}\right)$ reportada para la red del programa Investigaciones Mexicanas de la Corriente de California (IMECOCAL) durante el periodo de otoño a invierno (Gaxiola-Castro et al. 2010). Valle-Rodríguez y Trasviña-Castro (2017) determinaron el avance hacia el polo de una corriente cerca de la costa de la península de Baja California con velocidades de 0.2 a $0.3 \mathrm{~m} \cdot \mathrm{s}^{-1}$ en verano, la cual es probablemente responsable de los máximos de temperatura reportados en este estudio. En el periodo de 1998 a 2007, los resultados del programa IMECOCAL indicaron que la concentración de clorofila $a$ in situ en invierno y otoño fue menor en relación con los valores altos de primavera (Gaxiola-Castro et al. 2010). La biomasa del fitoplancton fue más alta en el periodo de surgencias intensas (marzo a julio) respecto a la menor biomasa registrada durante las surgencias débiles (agosto a febrero) (Fig. 7).

Las relaciones clorofila $a$ superficial versus clorofila $a$ integrada y clorofila $a$ integrada versus PP integrada presentaron correlaciones lineales significativas en el periodo de estudio. La ecuación (clorofila $a$ integrada) $=[(24.6 \times$ clorofila $a$ superficial +26$]$ permitirá estimar la concentración de la 
by cells $<20 \mu \mathrm{m}$ in size (nanophytoplankton). Studies of the Magdalena-Almejas lagoon system during conditions following the 1982-1983 El Niño event showed that nanoplankton was more abundant in August and September 1984, when temperature was high (Gárate-Lizárraga and Siqueiros-Beltrones 1998). Studies of phytoplankton structure in the Magdalena Bay system, under "normal" conditions in 1988 and 1989, showed that nanoplankton contributed the largest portion $\left(791,760\right.$ cells $\left.\cdot \mathrm{L}^{-1}\right)$ of total phytoplankton abundance throughout the sampling period, especially at the beginning of 1989 , and it was dominant mainly at the surface and at $10 \mathrm{~m}$ depth (Gárate-Lizárraga et al. 2001). In this study, nanophytoplankton abundance was highest $\left(1,719,284\right.$ cells $\cdot \mathrm{L}^{-1}$ at the surface) on 28 June 2013 . The nanoplankton fraction, which was represented by coccolithophores, comprised a significant portion (almost $90 \%$ of total cells) of phytoplankton abundance off Magdalena Bay during an El Niño event in April 1998, but chain-forming diatoms larger in size were highly abundant (up to $6.7 \times 10^{5}$ cells $\cdot \mathrm{L}^{-1}$ ) in December 1998 (Hernández-Becerril et al. 2007). The presence of coccolithophores was not evident in the samples analyzed during the present study possibly because of the sampling and analytical methods used.

Evidence indicates that the high picoplankton and cyanobacterium abundances, determined from coccoid counts and zeaxanthin concentrations, in upwelling areas off Baja California are associated with upwelling events and high nutrient concentrations (Díaz and Maske 2000, Linacre clorofila $a$ integrada en la zona eufótica a partir de la clorofila $a$ superficial. La correlación entre clorofila $a$ integrada y PP integrada que se encontró en el presente estudio resultó análoga a la reportada para el área de IMECOCAL en las 4 estaciones del año. La ecuación que permitirá calcular la PP integrada a partir de los datos de clorofila $a$ integrada es la siguiente: $($ PP integrada $)=[(1.8 \times$ clorofila $a$ integrada $)+16]$.

La abundancia del fitoplancton, estimada tanto por citometría de flujo como por microscopía (en abril, mayo y junio), estuvo dominada por las células $<20 \mu \mathrm{m}$ (nanofitoplancton). En estudios realizados en el sistema lagunar Magdalena-Almejas bajo condiciones posteriores al evento El Niño de 1982-1983 se reportó que el nanoplancton fue más abundante en agosto y septiembre de 1984, cuando las temperaturas fueron altas (Gárate-Lizárraga y Siqueiros-Beltrones 1998). Por otro lado, en estudios sobre la estructura del fitoplancton dentro del sistema de bahía Magdalena, bajo condiciones "normales" en 1988 y 1989, se encontró que el nanoplancton contribuyó con la mayor parte $\left(791,760\right.$ cél $\left.\cdot \mathrm{L}^{-1}\right)$ de la abundancia total del fitoplancton en todo el periodo de muestreo, particularmente a inicios de 1989, y dominó principalmente en superficie y a $10 \mathrm{~m}$ de profundidad (Gárate-Lizárraga et al. 2001). En este estudio se encontró que las mayores abundancias del nanofitoplancton (hasta $1,719,284$ cél $\cdot \mathrm{L}^{-1}$ en superficie) correspondieron al 28 de junio de 2013. La fracción del nanoplancton, representada por los cocolitofóridos, fue muy importante (casi 90\% del total de células) en la abundancia del fitoplancton frente a

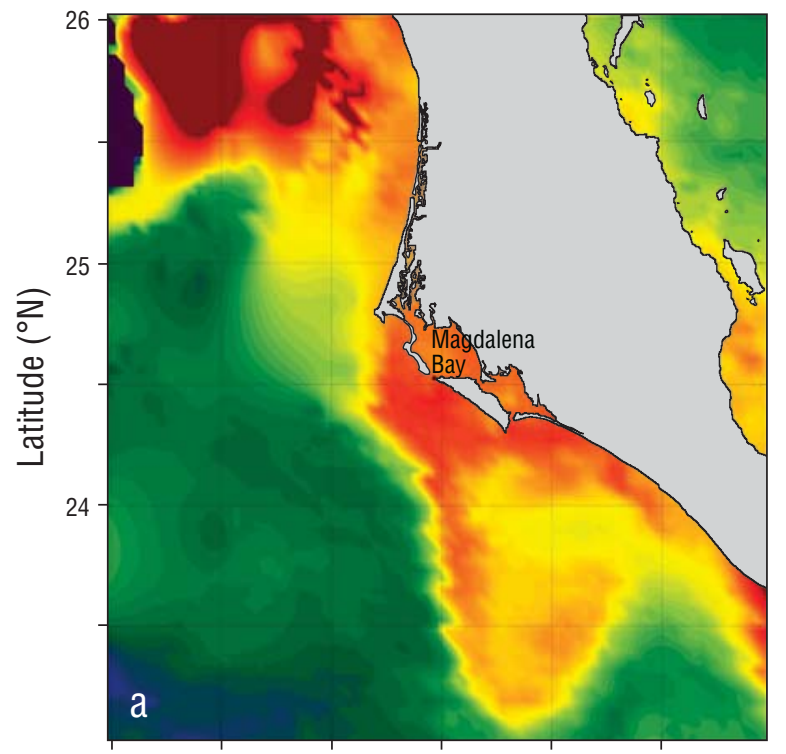

113

112

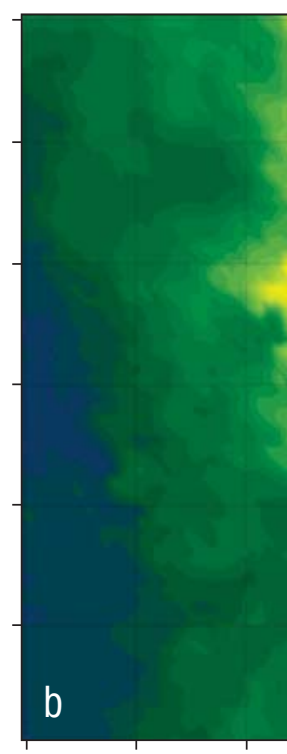

113
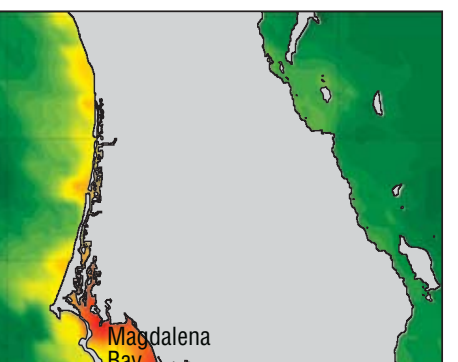

Chlorophyll a $\left(\mathrm{mg} \cdot \mathrm{m}^{-3}\right)$

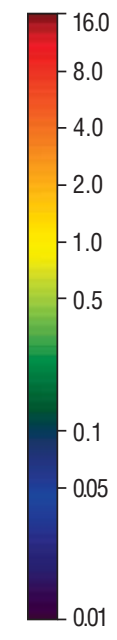

Longitude $\left({ }^{\circ} \mathrm{W}\right)$

Figure 7. Chlorophyll $a$ images for the Magdalena Bay region (Mexico), as derived from the Aqua-MODIS mean monthly composites (4 km resolution) from June (a) and September (b) 2013.

Figura 7. Imágenes de clorofila $a$ en la región de bahía Magdalena, México, derivadas de las composiciones promedio mensuales (resolución de $4 \mathrm{~km}$ ) de la plataforma MODIS-Aqua en junio (a) y septiembre (b) de 2013. 
et al. 2010, Murillo-Murillo et al. 2013). The environmental characteristics of upwelling areas support the "rising tide" hypothesis, which suggests that nutrient increase improves the growth conditions of all phytoplankton sizes including picoplankton (Barber and Hiscock 2006). High abundance of phytoplankton $<20 \mu \mathrm{m}$ (nanoplankton and picoplankton) in upwelling areas such as Magdalena Bay suggests that this fraction makes an important contribution to biomass and PP, especially under mixing and weak stratification conditions (Murillo-Murillo et al. 2013). However, highest productivity has been observed in the March-July period, when upwelling events are most intense, and productivity declines have been observed as upwelling frequency and intensity decrease (Cervantes-Duarte et al. 2015). The high abundances of cells $<20 \mu \mathrm{m}$ recorded by flow cytometry and microscopy in April, May, and June 2013 indicate that this size could be as relevant as microphytoplankton sizes, as was reported by Martínez-López and Verdugo-Díaz (2000) for the same region.

This study showed that the fraction of phytoplankton cells $<20 \mu \mathrm{m}$ made a large contribution to total phytoplankton abundance. In addition, the phytoplankton community in waters off Magdalena Bay showed seasonal variability, similar to that observed in other coastal upwelling regions, with higher phytoplankton abundances and production rates in spring and summer and lower between autumn and winter.

\section{ACKNOWLEDGMENTS}

This study was funded by the National Polytechnic Institute (Mexico, SIP-20130611) and by the National Council for Science and Technology (México, project CB-2011-01-167361 granted to JRLL). We thank the Mexican Society for Planktology and Beckman Coulter for providing the CyAN ADP cytometer, and Aldo Aquino-Cruz and Sergio Hernández-Trujillo for their collaboration and mentorship during the application of the flow cytometry technique.

English translation by Claudia Michel-Villalobos.

\section{REFERENCES}

Andersen P, Throndsen J. 2004. Estimating cell numbers. In: Hallegraeff GM, Anderson DM, Cembella AD (eds.), Manual on Harmful Marine Microalgae. UNESCO, Paris (France), pp. 99-129.

Aquino-Cruz A, Hernández-Becerril DU, Signoret-Poillon M, Salas-de-León DA, Monreal-Gómez MA. 2013. Studies on picophytoplankton in the southern Gulf of Mexico: recognition of picoprokaryotes and abundances of picophytoplankton during "dry season". Braz. J. Oceanogr. 61(4): 265-276. https://doi.org/10.1590/s1679-87592013000400007

Auad G, Roemmich D, Gilson J. 2011. The California Current System in relation to the Northeast Pacific Ocean circulation. Prog. Oceanogr. 91(4): 576-592. https://doi.org/10.1016/j.pocean.2011.09.004

Barber RT, Hiscock MR. 2006. A rising tide lifts all phytoplankton: Growth response of other phytoplankton taxa in diatomdominated blooms. Global Biogeochem. Cycles 20(4): GB4S03. http://doi.org/10.1029/2006GB002726 bahía Magdalena en abril de 1998, durante un evento El Niño, mientras que para diciembre del mismo año, las diatomeas formadoras de cadenas y de mayor talla fueron muy abundantes (hasta $6.7 \times 10^{5}$ cél $\cdot \mathrm{L}^{-1}$ ) (Hernández-Becerril et al. 2007). En las muestras analizadas en el presente estudio, la presencia de cocolitofóridos no se hizo evidente, quizás por el protocolo de recolecta y análisis utilizado.

En las zonas de surgencia frente a Baja California, existen evidencias de que las abundancias de células de picoplancton y cianobacterias, determinadas a través de los conteos de coccales y la concentración de zeaxantina, son altas y están asociadas a afloramientos y concentraciones altas de nutrientes (Díaz y Maske 2000, Linacre et al. 2010, Murillo-Murillo et al. 2013). Las características ambientales asociadas a las zonas de surgencia apoyan la hipótesis "rising tide", que propone que el incremento de nutrientes mejora las condiciones de crecimiento de todas las tallas de fitoplancton, incluso el picofitoplancton (Barber y Hiscock 2006). La abundancia alta del fitoplancton de talla $<20 \mu \mathrm{m}$ (nano y picoplancton) en zonas de afloramiento como la de bahía Magdalena sugiere que esta fracción hace una contribución importante a la biomasa y a la PP, especialmente bajo condiciones de mezcla y estratificación débil (Murillo-Murillo et al. 2013). Sin embargo, la productividad mayor se ha observado en el periodo de marzo a julio, cuando las surgencias son más intensas, y la disminución de la productividad se ha observado cuando la intensidad y la frecuencia de las surgencias son menores (Cervantes-Duarte et al. 2015). Las abundancias altas de células $<20 \mu \mathrm{m}$ registradas por citometría de flujo y por microscopía en abril, mayo y junio de 2013 mostraron que esta talla puede ser tan relevante como la del microfitoplancton, tal como lo reportaron Martínez-López y Verdugo-Díaz (2000) para esta misma región.

Este estudio mostró la gran contribución a la abundancia del fitoplancton total por parte de la fracción de células menores que $20 \mu \mathrm{m}$. Además, la comunidad del fitoplancton de las aguas frente a bahía Magdalena presentó una variabilidad estacional, similar a lo observado en otras regiones características de afloramientos costeros; es decir, las abundancias y tasas de producción fitoplanctónicas fueron mayores en primavera y verano y menores en otoño e invierno.

\section{Agradecimientos}

Este estudio fue apoyado con recursos del Instituto Politécnico Nacional (México, SIP-20130611) y el Consejo Nacional de Ciencia y Tecnología (México, proyecto CB-2011-01-167361 otorgado a JRLL). Agradecemos a la Sociedad Mexicana de Planctología y a Beckman Coulter la facilitación del citómetro CyAn ADP, y a Aldo Aquino-Cruz y Sergio Hernández-Trujillo su colaboración y asesoría en la aplicación de la técnica de citometría de flujo. 
Cervantes-Duarte R, Aguiñiga-García S, Hernández-Trujillo S. 1993. Upwelling conditions associated to the distribution of zooplankton in San Hipolito, B.C.S. = Condiciones de surgencia asociadas a la distribución de zooplancton en San Hipolito, B.C.S. Cienc. Mar. 19(1): 117-135. https://doi.org/10.7773/cm.v19i1.917

Cervantes-Duarte R, Prego R, Gaxiola-Castro G, López-López S, Aguirre-Bahena F, Murillo-Murillo I. 2015. Intra-annual upwelling patterns and its linkage with primary production in the euphotic zone $\left(24.5^{\circ} \mathrm{N}\right)$ of Southern Baja California coast. Estuar. Coast. Shelf Sci. 157: 51-58. https://doi.org/10.1016/j.ecss.2015.02.008

Chavez FP, Messié M. 2009. A comparison of Eastern Boundary Upwelling Ecosystems. Prog. Oceanogr. 83(1-4): 80-96. https://doi.org/10.1016/j.pocean.2009.07.032

Chavez FP, Toggweiler JR. 1995. Physical estimates of global new production. In: Summerhayes CP, Emeis KC, Angel MV, Smith RI, Zeitzschel B (eds.), Upwelling in the ocean: modern processes and ancient records. John Wiley and Sons, Chichster (United Kingdom), pp. 103-124.

[CONAPESCA] Comisión Nacional de Acuacultura y Pesca. 2013. Anuario Estadístico de Acuacultura y Pesca. [Downloaded 9 January 2015] CONAPESCA, http://www.conapesca.gob.mx/ work/sites/cona/dgppe/2013/ANUARIO_ESTADISTICO_DE_ ACUACULTURA_Y_PESCA_2013.zip.

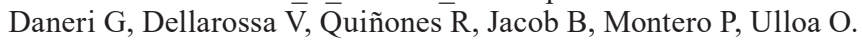
2000. Primary production and community respiration in the Humboldt Current System off Chile and associated oceanic areas. Mar. Ecol. Prog. Ser. 197: 41-49.

https://doi.org/10.3354/meps197041

Díaz C, Maske H. 2000. Abundance of coccoid cyanobacteria, hydrographic parameters and the possible underestimation of in situ chlorophyll a in the northern Gulf of California and the Mexican California Current $=$ Abundancia de cianobacterias cocales, parámetros hidrográficos y la posible subestimación de la clorofila a in situ en el norte del Golfo de California y la corriente de California, México. Cienc. Mar. 26(3): 441-461.

https://doi.org/10.7773/cm.v26i3.594

Durazo R. 2009. Climate and upper ocean variability off Baja California, Mexico: 1997-2008. Prog. Oceanogr. 83(1-4): 361-368. https://doi.org/10.1016/j.pocean.2009.07.043

Durazo R, Baumgartner TR. 2002. Evolution of oceanographic conditions off Baja California: 1997-1999. Prog. Oceanogr. 54(1-4): 7-31. https://doi.org/10.1016/s0079-6611(02)00041-1

Durazo R, Ramírez AM, Miranda LE, Soto-Mardones LA. 2010. Climatología de variables hidrográficas. In: Gaxiola-Castro G, Durazo R (eds.), Dinámica del Ecosistema Pelágico frente a Baja California, 1977-2007: Diez Años de Investigaciones Mexicanas de la Corriente de California. Secretaría de Medioambiente y Recursos Naturales, Mexico City (Mexico), pp. 25-57.

Gárate-Lizárraga I, Siqueiros-Beltrones DA. 1998. Time variation in phytoplankton assemblages in a subtropical lagoon system after the 1982-1983 "EI Niño" Event (1984 to 1986). Pac. Sci. 52(1): 79-97.

Gárate-Lizárraga I, Verdugo-Díaz G, Siqueiros-Beltrones DA. 2001. Variations in phytoplankton during 1988-1989 in a subtropical lagoon system of the west coast of Mexico. Oceánides 16(1): 1-16.

Gaxiola-Castro G, Cepeda-Morales J, Nájera-Martínez S, Espinosa-Carreón TL, De la Cruz-Orozco ME, Sosa-Avalos
R, Aguirre-Hernández E, Cantú-Ontiveros JP. 2010. Biomasa y producción del fitoplancton. In: Gaxiola-Castro G, Durazo R (eds.), Dinámica del Ecosistema Pelágico frente a Baja California, 1997-2007: Diez Años de Investigaciones Mexicanas de la Corriente de California. Secretaría de Medioambiente y Recursos Naturales, Mexico City (Mexico), pp. 59-87.

Hasle GR. 1978. Using the inverted microscope. In: Sournia A (ed.), Phytoplankton Manual. UNESCO, Paris (France), pp. 191-196.

Hernández-Becerril DU, Bravo-Sierra E, Aké-Castillo JA. 2007. Phytoplankton on the western coasts of Baja California in two different seasons in 1998. Sci. Mar. 71(4): 735-743. https://doi.org/10.3989/scimar.2007.71n4735

Hill AE, Hickey BM, Shillington FA, Strub PT, Brink KH, Barton ED, Thomas AC. 1998. Eastern ocean boundaries: coastal segment (E). In: Robinson AR, Brink KH (eds.), The Sea. The Global Coastal Ocean, Regional Studies and Syntheses, vol. 11. John Wiley and Sons, USA, pp. 29-67.

Kahru M, Kudela R, Manzano-Sarabia M, Mitchell BG. 2009. Trends in primary production in the California Current detected with satellite data. J. Geophys. Res.: Oceans 114(C2): C02004. https://doi.org/10.1029/2008jc004979

Kirk JTO. 1994. Light and Photosynthesis in Aquatic Ecosystems. Cambridge Univ. Press, United Kingdom, 509 pp.

Linacre LP, Landry MR, Lara-Lara JR, Hernández-Ayón JM, Bazán-Guzmán C. 2010. Picoplankton dynamics during contrasting seasonal oceanographic conditions at a coastal upwelling station off Northern Baja California, México. J. Plankton Res. 32(4): 539-557. https://doi.org/10.1093/plankt/fbp148

López-Sandoval DC, Lara-Lara JR, Lavín MF, Álvarez-Borrego S, Gaxiola-Castro G. 2009. Primary productivity in the eastern tropical Pacific off Cabo Corrientes, Mexico = Productividad primaria en el Pacífico oriental tropical adyacente a Cabo Corrientes, México. Cienc. Mar. 35(2): 169-182. https://doi.org/10.7773/cm.v35i2.1530

Lluch-Belda D, Lluch-Cota DB, Lluch-Cota SE. 2003. Baja California's biological transition zones: refuges for the California sardine. J. Oceanogr. 59(4): 503-513.

Lynn RJ, Simpson JJ. 1987. The California Current system: the seasonal variability of its physical characteristics. J. Geophys. Res. 92(C12): 12947-12966. https://doi.org/10.1029/jc092ic12p12947

Martínez-López A, Verdugo-Díaz G. 2000. Composición y dinámica del fitoplancton en El BAC de Bahía Magdalena, B.C.S. In: Lluch-Belda D, Elorduy-Garay J, Lluch-Cota SE, Ponce-Díaz G (eds.), BAC Centros de Actividad Biológica del Pacífico Mexicano. Centro de Investigaciones Biológicas del Noroeste, La Paz, Baja California Sur (Mexico), pp. 125-142.

Murillo-Murillo I, Cervantes-Duarte R, Gaxiola-Castro G, LópezLópez S, Aguirre-Bahena F, González-Rodríguez E, JiménezIllescas AR, Hernández-Sandoval FE. 2013. Variabilidad de la productividad primaria y de pigmentos fotosintéticos en una zona de surgencias de la región sur de la corriente de California. CICIMAR Océanides 28(1): 23-26.

Parsons TR, Maita Y, Lalli CM. 1984. A Manual of Chemical and Biological Methods for Seawater Analysis. Pergamon Press, Oxford (NY), 173 pp.

Pérez-Brunius P, López M, Parés-Sierra A, Pineda J. 2007. Comparison of upwelling indices off Baja California derived from three different wind data sources. CalCOFI Rep. 48: 204-214. 
Pilson MEQ. 2013. An introduction to the chemistry of the sea. 2nd ed. University of Rhode Island, Rhode Island, $521 \mathrm{pp}$.

Redfield AC, Ketchum BH, Richards FA. 1963. The influence of organisms on the composition of sea-water. In: Hill MN (ed.), The Sea, vol. 2. Interscience Publishers, USA, pp. 26-77.

Sherr EB, Sherr BF, Wheeler PA. 2005. Distribution of coccoid cyanobacteria and small eukaryotic phytoplankton in the upwelling ecosystem off the Oregon coast during 2001 and 2002. Deep Sea Res., Part II 52(1-2): 317-330. https://doi.org/10.1016/j.dsr2.2004.09.020

Steeman-Nielsen E. 1952. The use of radio-active carbon (C14) for measuring organic production in the sea. ICES J. Mar. Sci. 18(2): $117-140$. https://doi.org/10.1093/icesjms/18.2.117

Strickland JDH, Parsons TR. 1972. A Practical Handbook of Seawater Analysis, vol. 167. 2nd ed. Fisheries Research Board of Canada, Ottawa (ON), $310 \mathrm{pp}$.

Strub PT, Mesías JM, Montecino V, Rutllant J, Salinas S. 1998. Coastal ocean circulation off western South America. In: Robinson AR, Brink KH (eds.), John Wiley and Sons, New York, pp. 273-313.

Utermöhl H. 1958. Zur Vervollkcommnung der quatitative Phytoplankton Methodik. Mitt. Int. Ver. Limnol. 9: 1-38.

Valle-Rodríguez J, Trasviña-Castro A. 2017. Poleward currents from coastal altimetry: The west coast of Southern Baja California, Mexico. Adv. Space Res. 59(9): 2313-2324.

http://dx.doi.org/10.1016/j.asr.2017.01.050
Varela M, Álvarez-Ossorio Ma T, Bode A, Prego R, Bernárdez P, Garcia-Soto C. 2010. The effects of a winter upwelling on biogeochemical and planktonic components in an area close to the Galician Upwelling Core: The Sound of Corcubión (NW Spain). J. Sea Res. 64(3): 260-272. https://doi.org/10.1016/j.seares.2010.03.004

Venrick EL, Hayward TL. 1984. Determining Chlorophyll on the 1984 CALCOFI Surveys. CalCOFI, Rep. 25: 74-79.

Walsh JJ, Whitledge TE, Kelley JC, Hunstman SA, Pillsbury RD. 1977. Further transition states of Baja California upwelling ecosystem. Limnol. Oceanogr. 22(2): 44-60.

Watson JV. 2005. Flow cytometry data analysis, basic concepts and statistics. Cambridge Univ. Press, United Kingdom, 296 pp.

Wetz MS, Wheeler PA. 2004. Response of bacteria to simulated upwelling phytoplankton blooms. Mar. Ecol. Progr. Ser. 272: 49-57. https://doi.org/10.3354/meps272049

Zaytsev O, Cervantes-Duarte R, Montante O, Gallegos-Garcia A. 2003. Coastal upwelling activity on the Pacific shelf of the Baja California Peninsula. J. Oceanogr. 59(4): 489-502.

Zaitsev O, Trasviña-Castro A, Linero-Cueto J, Gaxiola-Castro G, Cepeda-Morales J. 2014. Oceanographic conditions over the continental shelf off Magdalena Bay (Mexico) in 2011-2012 = Condiciones oceanográficas en la plataforma continental frente a bahía Magdalena (México) en 2011-2012. Cienc. Mar. 40(2): 89-112.

https://doi.org/10.7773/cm.v40i2.2314

Received March 2017, accepted January 2018. 